INTER NATIONAL MONETARY FUND
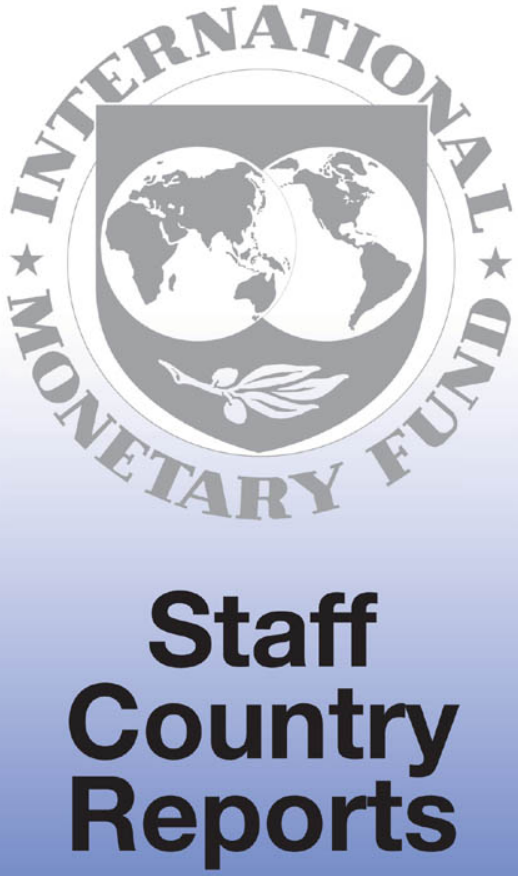


\section{United Republic of Tanzania: Ex Post Assessment of Longer-Term Program Engagement}

This Ex Post Assessment of Longer-Term Program Engagement for the United Republic of Tanzania was prepared by a staff team of the International Monetary Fund as background documentation for the periodic consultation with the member country. It is based on the information available at the time it was completed on March 21, 2006. The views expressed in this document are those of the staff team and do not necessarily reflect the views of the government of the United Republic of Tanzania or the Executive Board of the IMF.

The policy of publication of staff reports and other documents by the IMF allows for the deletion of market-sensitive information.

To assist the IMF in evaluating the publication policy, reader comments are invited and may be sent by e-mail to publicationpolicy@imf.org.

Copies of this report are available to the public from

International Monetary Fund • Publication Services

700 19th Street, N.W. • Washington, D.C. 20431

Telephone: (202) 6237430 • Telefax: (202) 6237201

E-mail: publications@imf.org • Internet: http://www.imf.org

Price: $\$ 15.00$ a copy

\section{International Monetary Fund Washington, D.C.}


This page intentionally left blank

(C) International Monetary Fund. Not for Redistribution 


\section{INTERNATIONAL MONETARY FUND \\ UNITED REPUBLIC OF TANZANIA}

\section{Ex Post Assessment of Longer-Term Program Engagement}

Prepared by staff team from the African, Fiscal Affairs, Monetary and Financial Systems, and Policy Development and Review Departments ${ }^{1}$

Authorized for Distribution by African and Policy Development and Review Departments

March 21, 2006

Contents

Executive Summary $\underline{3}$

I. Introduction .$\underline{4}$

II. Objectives of Fund-Supported Programs .$\underline{5}$

III. Program Performance Relative to Objectives $\underline{6}$

A. What explains strong growth but the weak poverty response? ................................

B. Why has private sector performance been weak? ................................................... 9

C. What has underpinned fiscal adjustment in Tanzania? ..........................................11

D. Did aid inflows complicate monetary policy and macroeconomic management?.. 17

E. Were external and debt objectives achieved?.....................................................20

F. Have structural reforms improved the economy's supply response? ......................23

IV. Implementation Lessons, Program Design, and Conditionality ……………..................26

A. What explains the relative success of Fund-supported programs in Tanzania? …..26

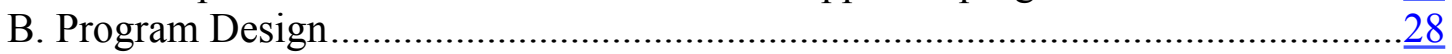

C. Conditionality and Compliance .......................................................................29

V. Policy Challenges for the Medium-Term.................................................................

VI. Strategy for Future Fund Involvement ……………..................................................

Tables

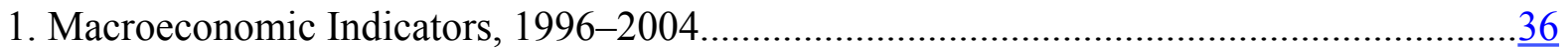

2. Doing Business in Sub-Saharan Africa: Selected Countries, 2005 ...................................

\footnotetext{
${ }^{1}$ The team was compromised of Mr. Srinivasan (Head, PDR), Mr. Adedeji (FAD), Ms. Everaert (AFR), Ms. Majaha-Jartby (MFD), and Ms. Ramakrishnan (PDR). Ms. Hakobyan (PDR) provided invaluable research assistance.
} 


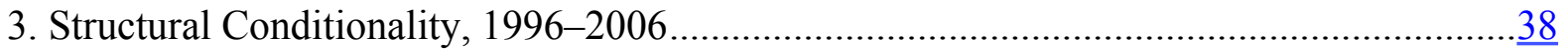

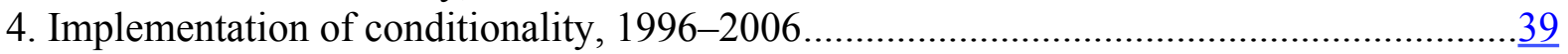

5. Millennium Development Goals ................................................................................

Figures

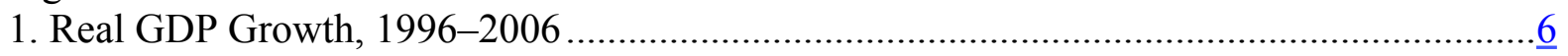

2. Decomposition of GDP Growth, 1996-2005 ...........................................................

3. Sectoral Contribution to GDP Growth, 1996-2005 ........................................................

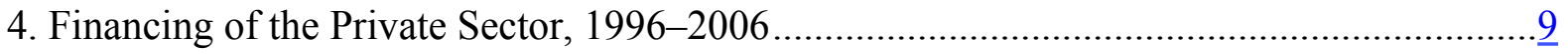

5. Comparison Transparency International Corruption Perception Index ...............................11

6. Central Government Expenditure, 1996-2006 …….....................................................12

7. Central Government Spending on Priority Sectors.........................................................12

8. Public Sector Employment and Wage Bill, 1995-2005 ……...........................................12

9. Central Government Revenue (excluding grants) 1996-2006.........................................14

10. Cross-Country Comparison of Revenue Performance, 2004/2005 ..................................15

11. Central Government Overall Balance, (after grants) 1996-2006 ……..............................16

12. Net Domestic Financing of the Government, 1996-2006 ...........................................16

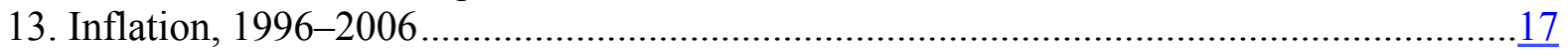

14. Net International Reserves of the Bank of Tanzania, 1996-2006 ……...........................18

15. Net Domestic Assets of the Bank of Tanzania, 1996-2006 …......................................18

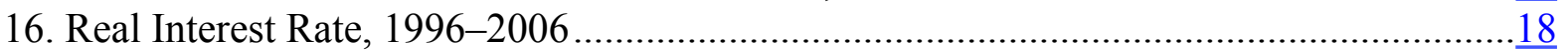

17. Current Account Deficit (including grants), 1996-2006 ................................................20

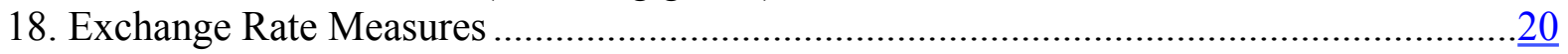

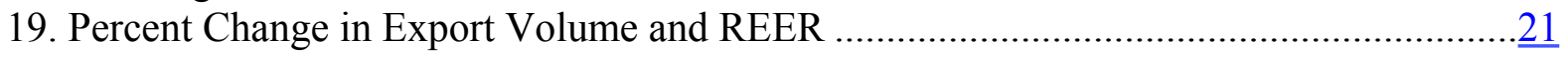

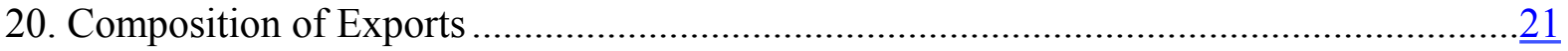

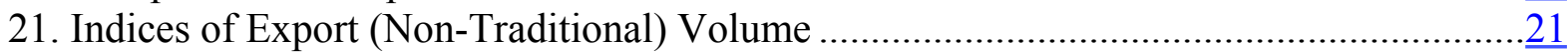

22. Exports of Goods and Services, 1997-2004 ..............................................................

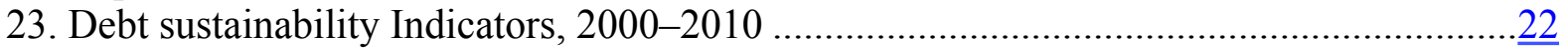

Appendices

1. Reforms Aimed at Private Sector Development ……......................................................

2. Experience With Managing Aid Flows...............................................................

3. Key Fiscal Reforms under Fund-supported Programs ....................................................

4. Financial Sector Reforms under the Fund-Supported Programs .......................................44

5. Compliance with Structural Conditionality Performance, 1996-2006 …............................

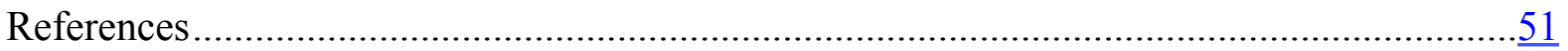




\section{Executive Summary}

Fund-supported programs in Tanzania since 1996 have been broadly successful in achieving rapid growth, low inflation, and a comfortable external position. Strong growth has, however, not translated into rapid poverty reduction, and is not mirrored in the expansion of private investment. Improvements in fiscal performance have been central to the success in macroeconomic stabilization, with substantial donor support helping to limit recourse to domestic financing, thereby enabling to reign in inflation. Large aid inflows have, however, complicated macroeconomic management. Debt relief under the enhanced HIPC Initiative was critical to restoring debt sustainability. Substantial structural reforms have been undertaken, but certain persistent deficiencies constrain Tanzania's growth prospects.

The design of the Fund-supported programs has been broadly appropriate and conditionality has been focused, although extensive in number. Programs were appropriately anchored on strengthening fiscal performance, sufficiently flexible to accommodate the large aid inflows, and adapted to facilitate greater aid absorption. The current monetary targeting framework, however, needs to be adapted to improve the liquidity management of the BoT, and provide more transparency with respect to its operations. Conditionality has generally been focused on achieving key program objectives, but despite streamlining, the number of structural conditions was greater than in other Fund-supported programs for low-income countries over the same period.

Program implementation improved progressively under successive Fund-supported programs. This can be attributed largely to strong political commitment to the reform process and ownership at the highest levels of the government and sustained donor support. Program implementation was fairly strong concerning fiscal reforms, reflected in improvements in expenditure management and, more recently, in revenue performance. At the same time, however, financial sector reforms, including the privatization of state-owned banks, have taken longer. Moreover, despite financial sector liberalization, financial intermediation remains modest, with large segments of the private sector, notably in the rural areas, having limited access to credit.

Several medium-term challenges remain. To make significant inroads into alleviating poverty and to reduce gradually the dependence on aid, Tanzania will need to sustain rapid growth for long periods, improve domestic revenue mobilization, and alleviate structural deficiencies. With large aid inflows expected over the medium term, greater coordination between fiscal and monetary policies would be critical to promote the spending and absorption of such flows. At the same time, to improve external competitiveness, it would be important to enhance the supply response and absorptive capacity of the economy.

Tanzania has no need for Fund resources going forward, but it could benefit from continued Fund engagement that goes beyond a pure surveillance relationship. In particular, rather than providing financial support, the most critical role for the Fund would be to provide signals to the donor community about the appropriateness of the government's policies. Against this background, a PSI would be an appropriate form of Fund engagement with Tanzania over the medium term. 


\section{INTRODUCTION}

1. By the late 1970s, Tanzania was a highly state-controlled economy, characterized by an inflexible economic system comprised of monopolistic and heavily regulated production structures. The rigid economic system, the war with Uganda, and external shocks during the late 1970s resulted in major macroeconomic imbalances, economic stagnation, and a decline in per capita income that lasted over 15 years. Following a shift in the mid-1980s away from administrative control of economic activity, progress was made in liberalizing external trade and payments, domestic prices, and agricultural marketing. In the early-1990s, Tanzania began pursuing market-oriented reforms, initiating a liberalization of the financial sector and of the civil service and, to a limited degree, privatization. Large segments of the economy, however, continued to be dominated by public sector monopolies and, more importantly, macroeconomic stability proved elusive.

\section{Since 1996, the Fund has supported Tanzania's reform efforts on a continuous}

basis. In the mid-1990s, Tanzania's economic reform and stabilization effort regained momentum following the first multiparty elections that were held in October 1995. In the first half of 1996, the newly elected government adopted a program monitored by the Fund staff aimed at addressing the fiscal imbalances and structural impediments that had hampered financial management. Performance under the Staff Monitored Program (SMP) was broadly successful. Following the SMP, three consecutive Fund-supported arrangements have been in place between 1996 and 2006, first under the Enhanced Structural Adjustment Facility (ESAF, 1996-1999) and subsequently under the Poverty Reduction and Growth Facility (PRGF, 2000-03 and 2003-06).

3. Given the Fund's long-term engagement with Tanzania, this Ex-Post Assessment addresses the following questions: Have economic reforms in the context of Fundsupported arrangements placed the country on a path of sustainable growth and poverty reduction? Why has private sector performance been weak? What has underpinned fiscal adjustment in Tanzania? Has aid posed problems for macroeconomic management? And what are the medium-term challenges that need to be overcome for Tanzania to achieve durable economic growth that would reduce poverty consistent with achievement of the Millennium Development Goals (MDGs)? ${ }^{2}$

4. The paper is organized as follows. Section II lays out the objectives of Fundsupported programs in Tanzania. Section III analyzes performance under the programs, followed by a discussion in Section IV of key program design and implementation lessons and the appropriateness of conditionality. Policy challenges for the medium term are discussed in Section V, followed by a discussion of the strategy for future Fund involvement in Section VI.

\footnotetext{
${ }^{2}$ In addition to reviewing IMF documents related to Tanzania since the mid-1990s, this study draws on related studies by academics, the World Bank, recommendations of the joint Fund-Bank FSAP (2003), and interviews with IMF and World Bank staff and the authorities in Tanzania.
} 


\section{ObJeCtives of Fund-Supported Programs}

5. Against the backdrop of large macroeconomic imbalances, the key challenge at the onset of Fund engagement in Tanzania was to restore macroeconomic stability. Once this objective was met, the overarching challenge was to accelerate growth and alleviate poverty -including by placing greater emphasis on private sector development and improving the economy's supply response, and a reorientation of public expenditure toward social spending - and lay the basis for a gradual reduction in the dependence on aid.

6. The medium-term strategy underlying the program supported by the ESAF was primarily aimed at achieving macroeconomic stability. The program was based on strengthening fiscal performance, and central to this effort was improving the cashmanagement system, established under the SMP, and civil-service reform. Improvements in the fiscal balance were expected to reign in inflation. Structural reforms, including privatization and financial sector liberalization, were aimed at enhancing efficiency and improving competitiveness, with a view to enabling the private sector to play a greater role in economic activity.

7. With macroeconomic stability largely achieved under the ESAF arrangement, the objective of the first PRGF program (PRGF1) was to sustain the stability and create the conditions favorable for higher growth, with particular focus on poverty reduction. Growth was to be led by the private sector, predicated on further structural reforms. Policies to reduce poverty included a greater reorientation of expenditures toward social spending, consistent with the objectives and priorities laid out in the PRSP.

8. The 2003-06 program (PRGF2) aimed to accelerate investment-led growth and further reduce poverty. ${ }^{3}$ Program objectives were to be met through a three-pronged strategy, comprising of greater focus, relative to the previous programs, on increasing domestic government revenues, with a view to reducing gradually aid dependence; further liberalizing the trade regime; and enhancing the economy's supply response by removing key impediments to growth and improving the investment environment, with a view to boosting private sector development.

9. Objectives in the context of Fund-supported programs in Tanzania have been appropriate, and have evolved in a manner consistent with macroeconomic developments. The following section examines performance under the Fund-supported programs by posing a series of questions, with a view to assessing if program objectives were met.

\footnotetext{
${ }^{3}$ See Tanzania—Report on Discussions on a Possible New Poverty Reduction and Growth Facility Arrangement.
} 


\section{Program Performance Relative to ObJectives}

\section{Fund-supported programs in Tanzania have succeeded in establishing} macroeconomic stability, reflected in rapid growth, low inflation, and a reasonably comfortable external position (Table 1). Rapid growth has, however, not translated into a significant decline in poverty, and has not been led by a significant pick up in private investment. Fiscal consolidation has been central to the success in macroeconomic stabilization, with substantial donor support for the reform program reducing the need for domestic financing. Aid inflows have, however, complicated macroeconomic management, making policy trade offs more stark. Debt relief under the HIPC Initiative was critical in achieving debt sustainability, and the outlook has improved further following Tanzania's qualification for debt relief under the MDRI. While substantial structural reforms have been undertaken, certain persistent deficiencies continue to undermine Tanzania's growth prospects.

\section{A. What explains strong growth but the weak poverty response?}

\section{Tanzania's annual average} real growth rate of about 5 percent over the past decade was impressive, especially considering that the economy is dependent on rain-fed agriculture and is thus vulnerable to climatic conditions. Program objectives were broadly appropriate, but were generally not met under the ESAF-supported program, owing largely to adverse weather conditions (Figure 1). ${ }^{4}$ That said, growth rates averaging around 4 percent over the ESAF-supported

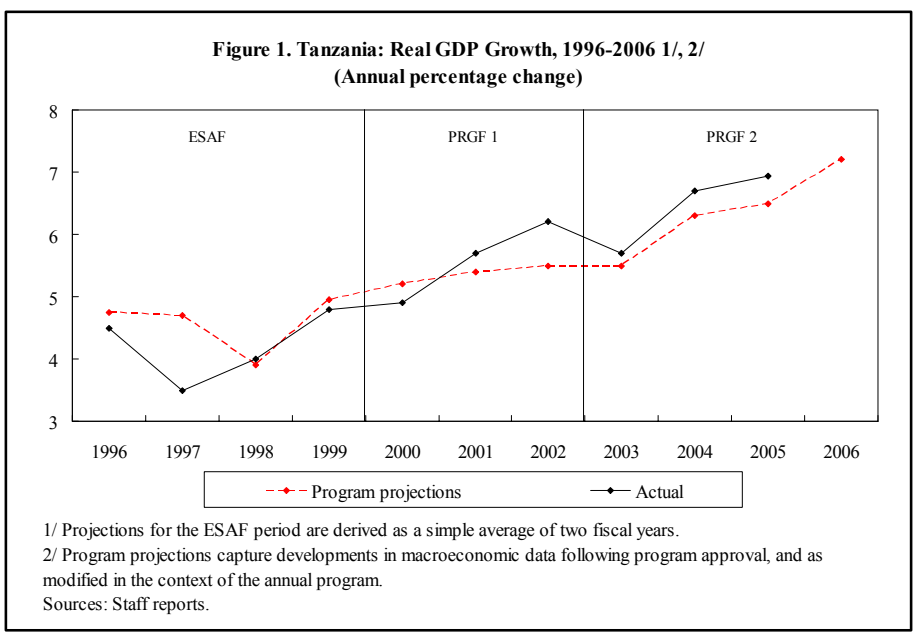
Sources: Staff reports. program period compared favorably with outcomes averaging less than 3 percent during 1990-95. Outcomes relative to program projections improved during the subsequent PRGF arrangements, with real GDP growth averaging about 6 percent per year.

\footnotetext{
${ }^{4}$ Economic growth in the context of the ESAF program was undermined, first by a drought in 1996/97 and subsequently by the El Niño floods in 1997/98.
} 
12. Growth has been largely driven by domestic demand, led by strong consumption

(Figure 2). A breakdown of the data suggests that since 2001, consumption demand was on average driven more or less equally by the public and private sectors. In this context, it is likely that some government aid-driven spending on education and health is classified as government consumption rather than investment, although these expenditures are likely to have a favorable long-term impact on the economy. Net exports have been rather flat. On the supplyside, agriculture - which accounts for about half of GDP and supports 80 percent of the
Figure 2. Tanzania: Decomposition of GDP Growth, 1996-2005 (Percentage points)

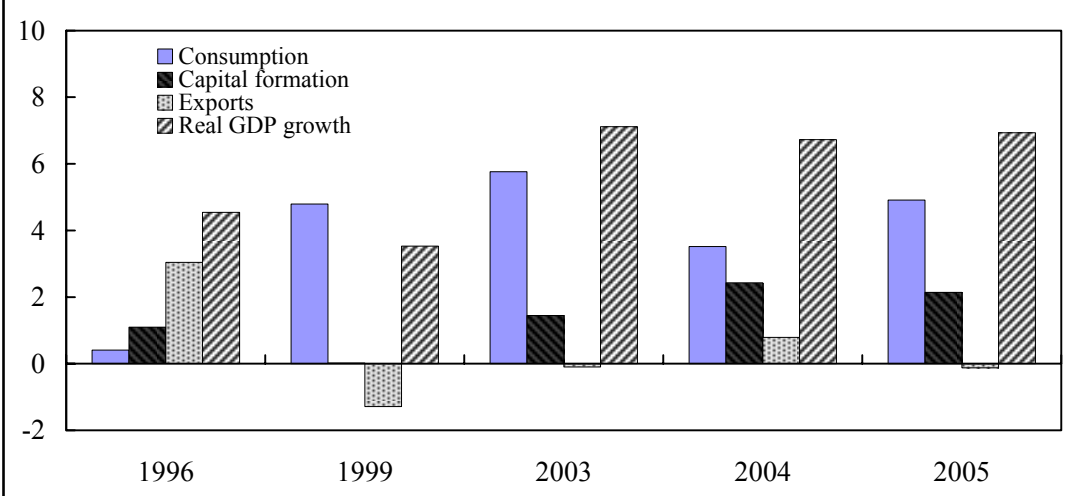

Figure 3. Tanzania: Sectoral Contribution to GDP Growth, 1996-2005 (Percentage points)

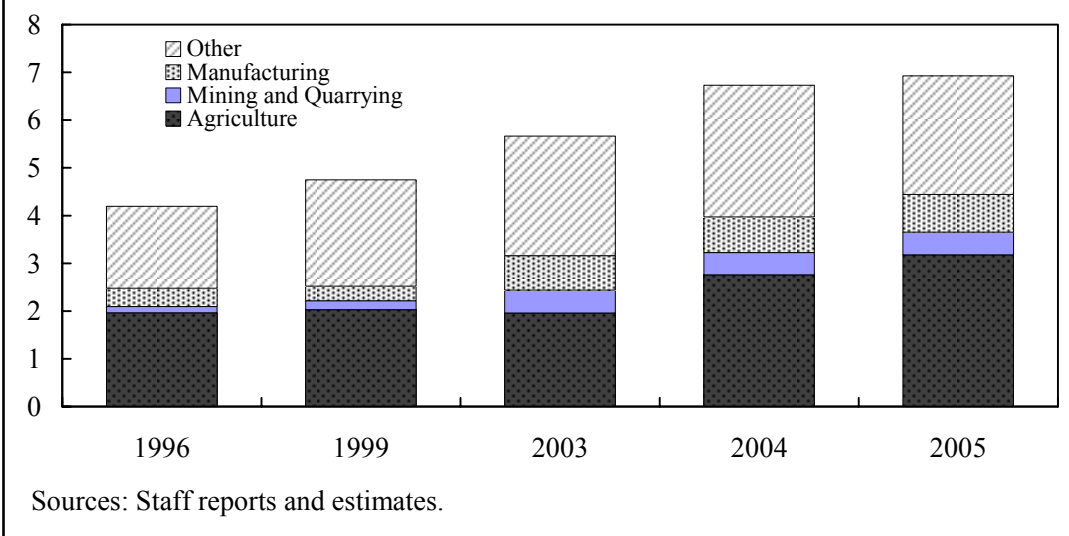

population - has been the predominant contributor to growth (Figure 3). Other sectors, including manufacturing, construction, and mining (reflecting large-scale gold mining operations) have recorded rapid growth in recent years, but their contribution to growth has been modest owing to the small size of these sectors.

\section{Rapid economic growth in the context of Fund-supported programs has not} translated into a noticeable reduction in poverty, which remains deep and pervasive, particularly in rural areas. Tanzania remains one of the poorest countries in the world, and among the poorest in sub-Saharan Africa. Indeed, while Tanzania's per capita GDP growth rate has averaged about 2 percent since 1996, and nearly 23/4 percent in 2000-05, it's GDP per capita, at about US\$337 in 2005, is well below sub-Saharan Africa's average of US\$568. The country ranked $160^{\text {th }}$ on the 2001 Human Development Index, below the average for subSaharan Africa.

- Based on the most recent Household Budget Survey (HBS) conducted in 2001, 36 percent of Tanzanians are still below the poverty line (and 19 percent are below the food poverty line), compared with 39 percent poverty rate in the $1991 \mathrm{HBS}$. Non-income based poverty measures also portray a grim picture, and have only improved modestly in the context of Fund-supported programs, notwithstanding a reorientation of public expenditure toward 
social spending. Based on 2004 data, life expectancy is 43 years, infant mortality rate is 104 per 1000 live births, and child malnutrition is 29 percent for children under 5 years. PRSP-related education expenditures have, however, been successful in boosting the literacy rate to 70 percent for ages 15 and over.

- Poverty in Tanzania has become more of a rural phenomenon, reflected in the fact that the poverty rate declined by 10 percentage points to about 18 percent in the capital Dar es Salaam between 1991 and 2001, whereas it declined by only 2 percentage points to 39 percent in the rural areas. Indeed, 87 percent of all poor people live in rural areas.

\section{It is somewhat of a puzzle as to why, despite rapid growth in the context of} Fund-supported programs, poverty reduction has been modest, particularly in rural areas. In this context, some considerations warrant a close look:

- It is quite possible that poverty reduction in Tanzania began to occur only after the economic stagnation through 1995 had been overcome and there was a greater reduction in poverty since then. This is, however, difficult to assess, because of the lack of annual survey data that could help analyze the correlation between the rate of poverty and GDP growth in the period between the two surveys, and since 2001. Simulations, however, suggest that poverty reduction in Tanzania might have been more rapid in recent years. ${ }^{5}$

- While annual GDP growth has averaged 5.2 percent since 1996, agricultural growth has on average been a full 1 percentage point lower, and this may have dampened poverty reduction in rural areas, where poverty is largely concentrated.

- Recent studies suggest that more than agriculture growth, it is the composition of such growth that bears upon poverty, and that the lack of sufficient diversification in agriculture production - away from food crops - has undermined poverty reduction in Tanzania. ${ }^{6}$ In particular, these studies find that poverty is lower in households that are involved in the production of cash crops and non-traditional agricultural goods (including horticulture and floriculture), all of which are exportable, than in households involved in the production of food crops. It is estimated, for example, based on data for 2005, that rural poverty would decline by 7 percent, if half of the households switched from food crops to cash crops.

\section{Reforms in the context of Fund-supported programs have helped boost and} diversify agricultural production and exports, but some of the more difficult issues have not been addressed. In particular, reforms have included the liberalization of agriculture production and marketing structures, as well as of agriculture prices and the foreign exchange regime. Programs have, however, not been able to address effectively supply-side

\footnotetext{
${ }^{5}$ Demombynes, G. and J.G.M. Hoogeveen, 2004, “Growth, Inequality, and Simulated Poverty Paths for Tanzania, 1992-2002," World Bank Policy Research Working Paper No. 3432.

${ }^{6}$ Tanzania: Diagnostic Trade Integration Study, The World Bank, June 2005.
} 
constraints - including reforms of state-owned crop boards; the proliferation of local taxes, which on some export commodities represent almost 20 percent of the sale price; weak rural infrastructure; the lack of adequate skills; and poor customs systems and procedures - all of which have undermined agricultural production and exports, and private investment, more generally.

\section{B. Why has private sector performance been weak?}

\section{Tanzania's strong economic growth of recent years is not mirrored in the} expansion of private sector investment. This might have dampened potentially faster growth and poverty reduction, and raises concerns about sustaining growth going forward.

- Out of the $6 \frac{1}{2}$ percent average real GDP growth during 2000-04, gross fixed capital formulation has contributed less than $13 / 4$ percentage points, although this was still an improvement over the previous five-year period. At the same time, gross private capital formation as a share of GDP declined from about 131/2 percent during 1995-99 to about 11 percent since 2000. Moreover, the share of private capital formation in total capital formation declined from about 80 percent in 1999 to 60 percent in 2005.

- Weaknesses in Tanzania's private investment are reflected in modest financial deepening and the low levels of bank claims on the private sector. While credit growth to the private sector increased quite rapidly under the Fund-supported programsaveraging about 35 percent since 2001 - it was from a very low base. This is reflected in the fact that net availability of funds to the private sector as a share of GDP, while continuing to increase in the context of the Fund-supported programs, has remained low

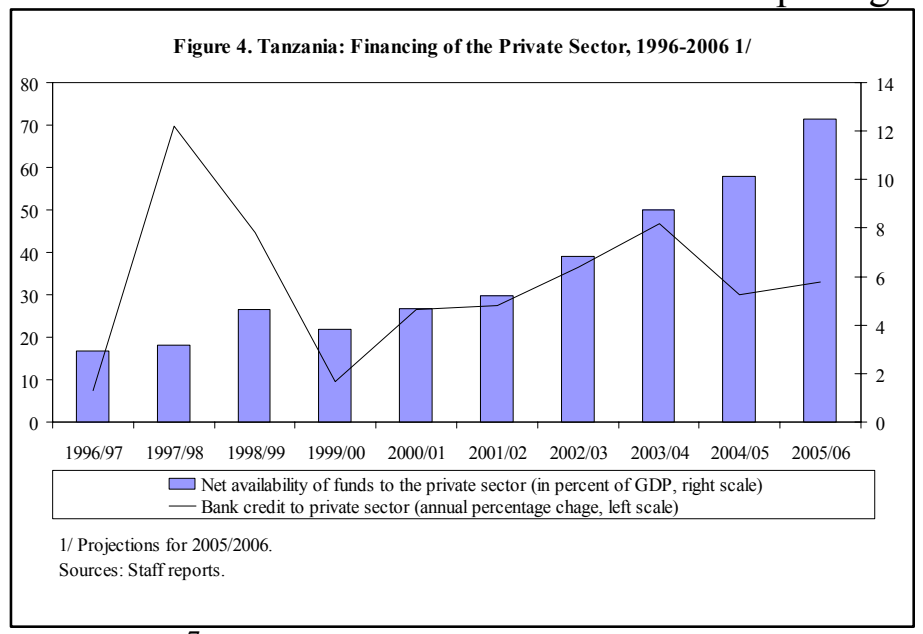
through most of the program period (Figure 4). ${ }^{7}$ More importantly, however, there has been a significant concentration of credit—with about 200 "bankable companies" accounting for a predominant share of bank credit to the private sector-and large segments in the private sector, notably in the rural areas, have had virtually no access to such financing.

- The modest role of the private sector is also reflected in export performance and the pattern of FDI inflows to the country. In particular, notwithstanding the large real depreciation of the shilling since 2000, the contribution of exports to GDP growth has not

\footnotetext{
${ }^{7}$ Net availability of funds to the private sector is defined as bank credit to the private sector minus non-bank financing of the budget.
} 
been significant. Similarly, while foreign direct investment inflows to Tanzania have been large, they have not been broad-based and have been largely limited to the mining sector. ${ }^{8}$ While it may be normal for foreign investors to first take the "low-hanging fruit," such FDI does not typically generate multiplier effects on growth or increase productivity through technology transfer that is associated with investment in the manufacturing and, to a lesser extent, in the services sector.

\section{A key reason why private sector participation in economic activity in Tanzania} has been modest is because the business environment is very poor. Based on the 2006 Doing Business In report of the World Bank, Tanzania ranks 140th in the overall ease of doing business out of 155 countries surveyed. Similarly, the World Economic Forum 2005, ranks Tanzania $82^{\text {nd }}$ out of 116 countries in the quality of the national business environment, and $71^{\text {st }}$ in the Growth Competitiveness Index out of 117 countries. In particular:

- Burdensome licensing procedures, reflected in high start-up costs, insufficient access to credit, restrictive labor regulations, difficulties in registering property and poor property rights, and very poor infrastructure are identified in the World Bank survey as some of the key factors undermining the business environment in Tanzania (Table 2).

- Poor infrastructure, for example, is best reflected in the pressing problems currently faced by the energy sector. The country is ranked $101^{\text {St }}$ out of 117 countries in the Global Competitiveness Report with respect to the production of electricity. Shortfalls in energy production and higher costs have undermined economic performance and the financial position of the state-owned power company (TANESCO).

- Investors also underscore corruption and poor governance as important factors undermining private investment in Tanzania. ${ }^{9}$ In this context, government regulations that encourage rent seeking, including the complex business licensing system, with overlapping regulatory mandates; the ad hoc provision of tax exemptions; and a corruptible legal system, that makes dispute resolution particularly onerous, are identified as key factors affecting investor sentiment.

\section{Fund-supported programs have been somewhat late in placing emphasis on} investment climate issues. Indeed, it was only in the context of PRGF2 that program objectives targeted explicitly an improvement in the investment climate. ${ }^{10}$ More generally,

\footnotetext{
${ }^{8}$ Net inflows of FDI have averaged about 4.2 percent of GDP per year in 2000-04.

${ }^{9}$ World Economic Forum Executive Opinion Survey, 2005; and Tanzania: Pilot Study on Access to Foreign Private Capital, unpublished IMF report, April 2003.

${ }^{10}$ At the same time, the government's dialogue with the private sector through the Investor's Roundtable meetings and the Tanzania National Business Council helped identify core problems impeding growth in the private and agricultural sector. Under the Business Environment Strengthening for Tanzania program (BEST), efforts were made to alleviate these impediments, notably to improve the economy's supply response (Appendix 2).
} 
once macroeconomic stability was achieved under the ESAF, Fund-supported programs could have placed greater emphasis on addressing the impediments undermining the investment climate, with a view to promoting sustainable investment-led growth. While some of these reforms - notably concerning the harmonization and streamlining of taxation; improving customs clearance procedures and administration; and access to credit - are broadly in the Fund's "core" areas of expertise, others would have had to involve greater collaboration with the World Bank and other donors.

\section{Governance issues received prominence in the PRGF- supported programs, and the perception of the severity of corruption in Tanzania has been improving, albeit gradually. Efforts} to improve governance were made in the broader context of stimulating growth and fiscal reform. ${ }^{11}$ Adopting a National Anti-Corruption Strategy and Action Plan (NACSAP) was a trigger for Tanzania reaching its completion point under the Enhanced

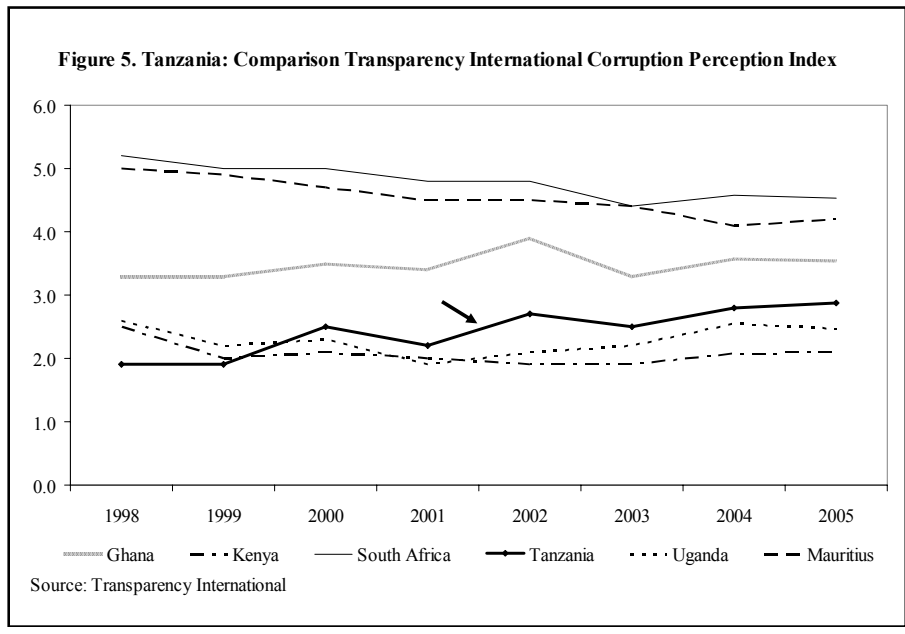
HIPC Initiative. The NACSAP focused on three areas-improving competence and attitude of the public service; increasing transparency; and strengthening the legislative and judiciary framework. The implementation of measures identified in the NACSAP was monitored in the context of Fund-supported programs through benchmarks. While Tanzania has improved its ranking on the corruption perception index of Transparency International (Figure 5), there continue to be concerns about graft, including in the granting of concessions for the exploitation of natural resources, delays in responding to complaints about corruption, and in the effectiveness of the legal system and the courts to address such problems. Moreover, there is skepticism that measures taken in the context of the NACSAP have sufficient teeth.

\section{What has underpinned fiscal adjustment in Tanzania?}

20. Fiscal adjustment was led by improvements in expenditure management, which made up for disappointing performance for most of the period on the revenue front, with large aid inflows limiting recourse to domestic financing.

${ }^{11}$ A presidential commission was established in 1996 to report on corruption practices in Tanzania. 


\section{Expenditure management has improved substantially}

21. Improvements in public expenditure management have been key in anchoring fiscal adjustment, notably by helping align expenditures with overall fiscal targets in Fund-supported programs. ${ }^{12}$ This was facilitated by the adoption of a centralized payment system, limiting spending to cash availability, and the development of a medium-term expenditure framework (MTEF). Expenditures were monitored through benchmarks in the programs, which were adjusted to reflect outcomes of external financing relative to projections (Figure 6). The Public Expenditure Review (PER) process, which is conducted in collaboration with donors, has served as an important mechanism to prioritize expenditures-articulated in the PRSP — consistent with the overall objective of reducing poverty. As a result, the composition of expenditures improved in favor of allocations for the priority sectors, including health and education (Figure 7). This was facilitated, in part, by a decline in the wage bill following civil service reform (Figure 8), and in interest payments on account of lower financing requirements and debt relief provided by donors. Accumulation of arrears - which was a serious problem in the context of ESAF and PRGF1 - has been virtually eliminated during PRGF2, owing to the effective implementation of an integrated financial management system (IFMS).

22. Notwithstanding improvements in expenditure policy, certain large expenditures have been made in the context of Fund-supported programs, which were at odds with the objective of reducing poverty through a prioritization of spending.

\footnotetext{
${ }^{12}$ Tanzania meets 10 of the 16 benchmarks, concerning budget formulation, execution and reporting, used by

Bank-Fund staff to assess the quality of the public expenditure management system.
} 
- In particular, in the context of PRGF1, the government purchased an air traffic control system (ATC), which raised concern across civil society and the donor community, notably on the financing of the project and the lack of transparency. It was contestedand correctly so - that the supposedly concessional financing of the project by the private sector came at the expense of an inflated price for the ATC, and that procurement transactions lacked sufficient transparency.

- In this context, staff advised the authorities to include in future all public investment projects in the context of the public expenditure review (PER) process, so as to ensure proper prioritization of projects before spending commitments are made. Despite the government's commitments to do so, similar expenditures were undertaken in the context of PRGF2, including to construct a national stadium and a new parliament building, without these being reviewed by the PER process. While staff expressed concern with these expenditures, they were, however, accommodated in the program, including through adjustments in the program targets. ${ }^{13}$

- Fund-supported programs should have been more firm in opposing such spending, both because they were not a priority and since they raised concerns about transparency and accountability in decision-making.

23. Recent reforms have aimed at improving expenditure policy. In particular, the lack of comprehensiveness in the PER process is being addressed by putting in place internal budget guidelines to review line ministries' spending plans comprehensively in the MTEF, with clear links planned to the National Strategy for Growth and Reduction of Poverty (NSGRP) and on the basis of identifiable outcomes. The newly developed Strategic Budget Allocation System (SBAS) has ensured strategic linkages between NSGRP outcomes and the budget, providing an advanced framework for allocating and assessing the impact of poverty reducing expenditures.

\section{Revenue mobilization has been weak}

\section{Domestic revenue mobilization in the context of Fund-supported programs has been very weak, despite significant reforms.}

- Program targets concerning domestic revenues have straddled between being unrealistic under the ESAF, "unambitious" under PRGF1, and somewhat more appropriate under PRGF2. Targets under the ESAF arrangement were unrealistic, largely because they

\footnotetext{
${ }^{13}$ The construction of the Parliament building was an off-budget expenditure, based on a build-operate-transfer scheme financed by the state pension fund. The lease payments for the use of the building are, however, financed through the budget.
} 
did not reflect fully the impact of the envisaged fiscal reforms that had the potential to significantly reduce revenues; targets under PRGF1 were unambitious, especially since they were based on performance under the ESAF, where revenue mobilization was also adversely affected by weather-related decline in economic activity; and relative to the previous programs, revenue targets under PRGF2 reflected

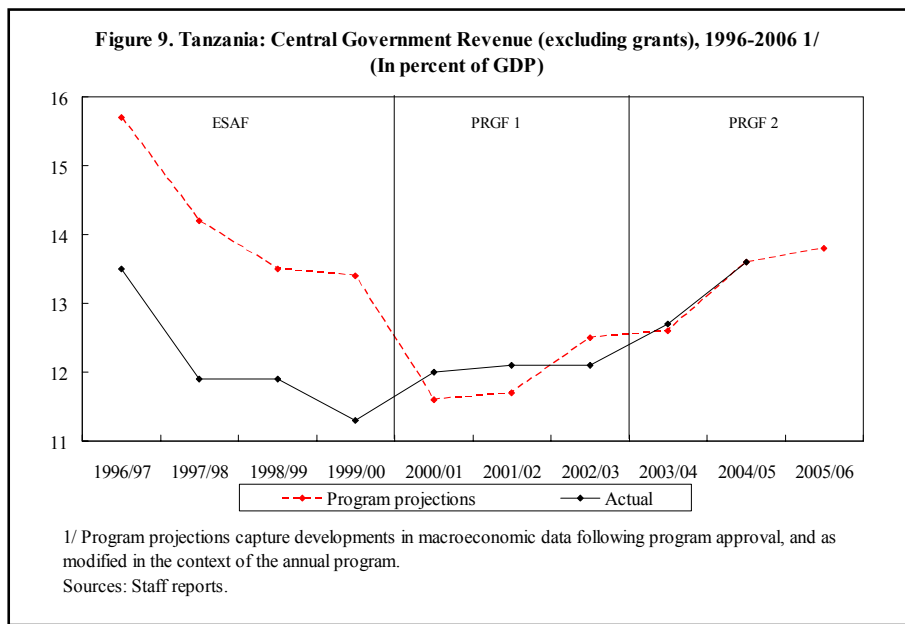
the program's greater emphasis on mobilizing revenue, and were broadly appropriate. Revenue outcomes were significantly below program projections in the context of the ESAF arrangement and generally better than projected under the PRGF arrangements (Figure 9). ${ }^{14}$

- While revenue performance under the first two of the Fund-supported programs was disappointing, this is not for want of trying. Indeed, significant reforms were undertaken, with a view to rationalizing the tax system and improving administration (Appendix 3).

- Revenue mobilization suffered, however, because tax collection and administration did not keep pace with the rationalization of the tax system and tariff reform; there was a proliferation of tax exemptions and incentives (including tax holidays), notably in the context of setting up export processing zones (EPA Act); and because the tax base moved gradually from a large, easy-to-tax public sector to a predominantly informal private sector in the course of the divestiture of many parastatals.

- Recognizing the weak revenue performance under the ESAF and PRGF1 and the need for significant catching up, boosting revenue mobilization was a key objective underpinning the design of PRGF2 - predicated on improvements in tax administration, based on technical assistance provided both by the Fund and other donors.

\footnotetext{
${ }^{14}$ The gap between revenue outcomes and the program targets under the ESAF also reflects revisions to nominal GDP. Even after accounting for revisions to GDP, outcomes were about 1-2 percentage points of GDP less than the targets under the ESAF-supported program.
} 


\section{Revenue performance has improved more recently, but there is still a large gap between revenue potential and the outcome.}

- There have been improvements in revenue mobilization in the context of PRGF2 - with revenues as a share of GDP increasing by about $2 \frac{1}{2}$ percentage points without any increase in tax rates.

- Notwithstanding this progress, there is still a considerable gap between revenue potential and outcome, estimated at about 3.6 percent of GDP. ${ }^{15}$ Also, central government revenue at 13.6 percent of GDP in 2004/05 compares poorly with other countries in the region (Figure 10).

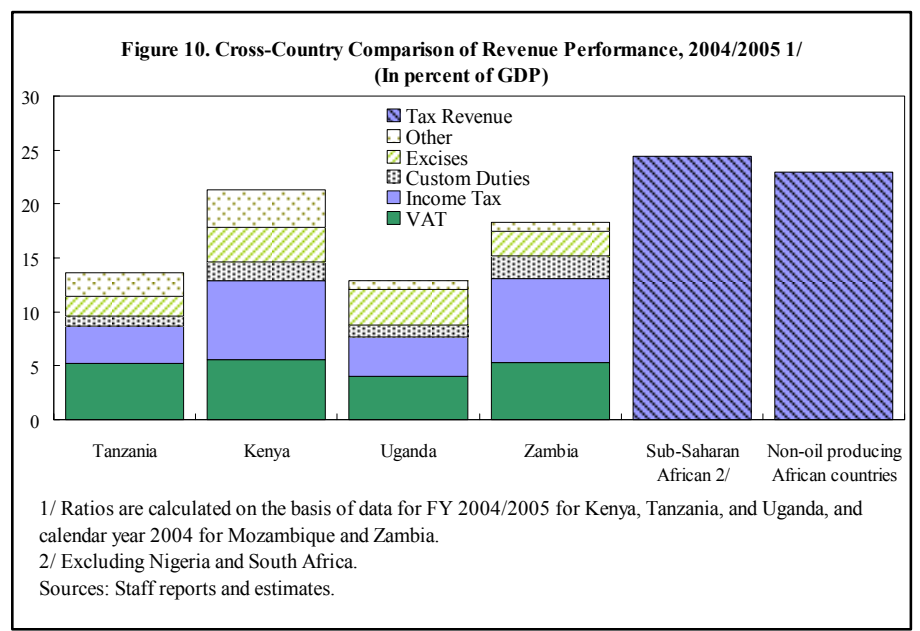

26. Moreover, despite the recent progress, central government revenues as a share of GDP have only recovered to the level prevailing at the onset of Fund engagement in Tanzania. This raises the question of whether aid inflows have undermined the government's resolve to bolster revenue mobilization. This is a difficult question to answer with any degree of certainty, but conceivably if greater emphasis had been paid in the context of the ESAF and PRGF1 on bolstering revenue mobilization, including by taking a firmer stance on the issue of tax exemptions and incentives and focusing technical assistance on improving tax administration consistent with the pace of tax and tariff reform, outcomes would likely have been more satisfactory.

\footnotetext{
${ }^{15}$ A recent FAD technical assistance mission on tax policy has estimated the tax capacity of Tanzania to be about 17.2 percent of GDP, similar to Uganda's and below those of Kenya and Malawi.
} 


\section{Deficits have been largely aid-financed}

27. The overall fiscal balance was broadly consistent with program objectives (Figure 11). Expenditure restraint to offset shortfalls in revenue mobilization and in foreign financing kept the overall fiscal balance close to program objectives. Over the program period, recourse to expenditure cuts to meet financing shortfalls declined, and as donor support for the budget increased markedly, Fund-supported programs allowed for a significant widening of the fiscal deficit before and after grants.
Figure 11. Tanzania: Central Government Overall Balance, (after grants), 1996-2006 1/ (In percent of GDP)

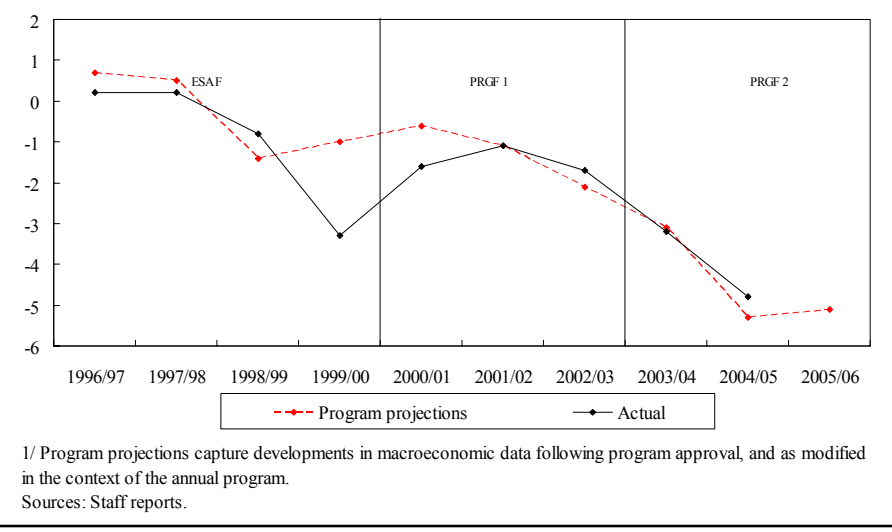

28. Fiscal deficits under the Fund-supported programs have been financed largely through external assistance, limiting recourse to domestic financing. Broadly, even at times when aid inflows were lower than projected, expenditure cuts (relative to program projections) have been relied upon to achieve the fiscal target. Indeed, targets concerning net domestic financing of the government-a performance criterion under the Fundsupported programs, which was adjusted for deviations in projected aid inflows - have almost always been met, and often by significant margins (Figure 12). On the one hand, not seeking recourse to domestic financing has helped limit a possible crowdingout of the private sector. This has been particularly relevant, since the

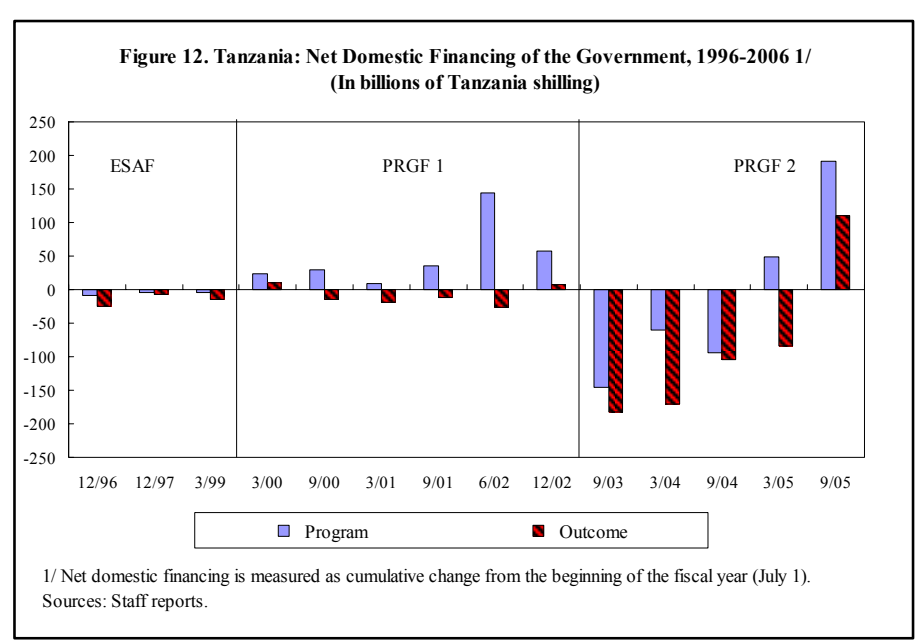
domestic debt market is relatively 
thin, because of which yields on government securities are highly sensitive to any significant change in government borrowing. ${ }^{16}$ On the other hand, this has on some occasions undermined expenditure smoothing, and underscores the need for greater coordination between fiscal and monetary policy and for deepening domestic debt markets.

\section{Did aid inflows complicate monetary policy and macroeconomic management?}

\section{The monetary policy objective of} reigning in inflation was largely

achieved. Inflation in Tanzania registered a continuous decline since the first program year, and reached single digits in 1999 for the first time in two decades. Following minor slippages in meeting ESAF program objectives, owing largely to weather-related food price increases, performance improved significantly under the PRGF programs. Inflation was broadly consistent with program objectives in PRGF1 and better than expected so far in PRGF2 (Figure 13). The key to the rapid decline in inflation was

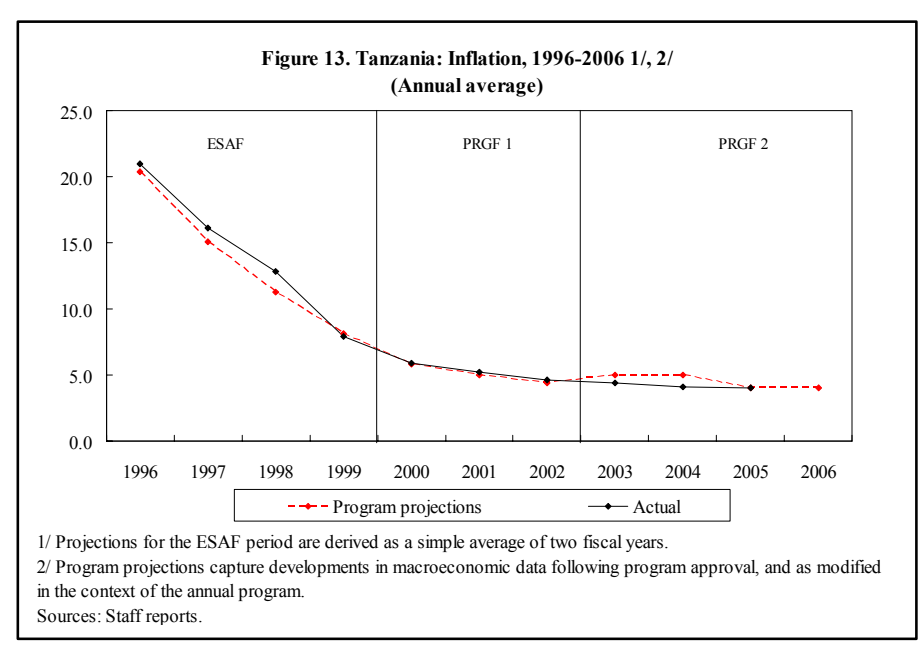
a tightening of monetary policy - based on improvements in fiscal performance and large aid inflows, which reduced the government's domestic financing needs - and favorable developments in agricultural output that helped contain increases in food prices.

\footnotetext{
${ }^{16}$ This was highlighted, most recently, in the context of PRGF2, when delays in donor disbursements in the first half of FY 2005/06 necessitated a net domestic borrowing of about 0.8 percent of GDP compared with -0.7 percent under the program, which contributed to a sharp increase in treasury bill rates (from 10 to 15 percent) and in the government's interest bill of about 0.6 percent of GDP.
} 


\section{Large aid inflows have, however, posed challenges for macroeconomic}

management. Program ceilings on the net domestic assets of the BoT and the floors on NIR were typically met by large margins (Figures 14 and 15).

- The policy response to greaterthan-projected aid inflows in the context of the ESAF and initially under PRGF1 (between 1999 and 2000) involved sterilization through the sale of treasury bills, largely because inflation was still considered to be on the higher side and international reserves were at relatively low levels. This, however, led to a sharp increase in interest rates (Figure 16).

- Concerned with rising interest rates and upward pressures on the exchange rate, policy was subsequently modified in the context of PRGF1 in favor of unsterilized foreign reserve accumulation. This was based on an assessment that owing to confidence in domestic policymaking and falling inflation, demand for money had increased. As a result, program benchmarks on reserve money were exceeded,

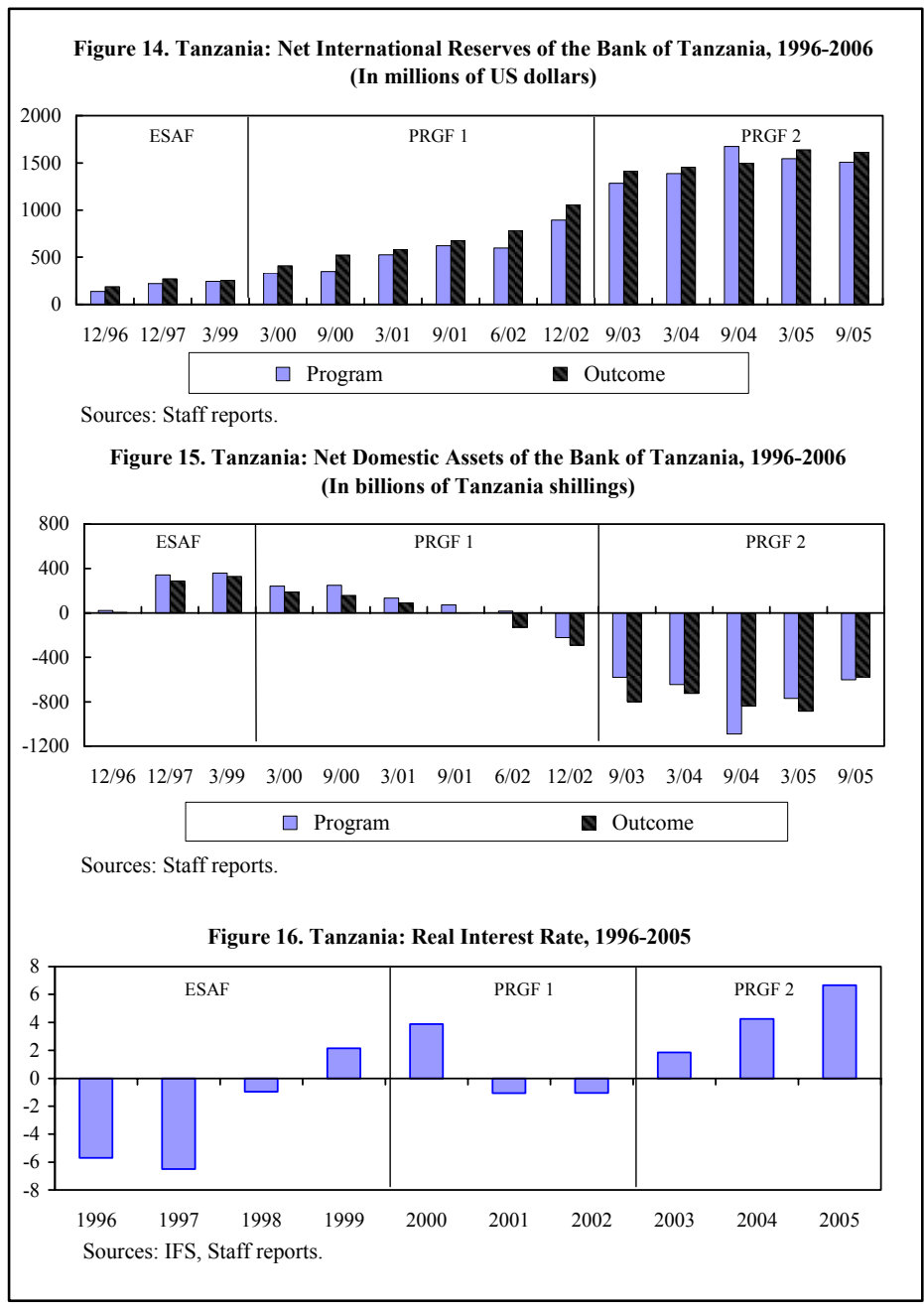
but the impact was not inflationary, implying that program benchmarks may have been tight or that the demand for money was underestimated. 
- In the context of PRGF2, concerned with the rapid rise in liquidity and the attendant inflationary risks, staff pushed, and appropriately so, for modifying the anchor for monetary policy to target reserve money rather than the net domestic assets of the BoT. ${ }^{17}$ As a result, the policy response to larger aid inflows has involved greater sales of foreign exchange to dampen inflationary pressures, a policy action rarely used previously for fears of currency appreciation, and has led to greater absorption of aid. That said, the full leeway provided under the programs for such sales has seldom been used.

\section{In the context of large aid inflows, balancing the conflicting objectives of} monetary and credit policy on the one hand and external competitiveness and export performance on the other has been a challenge for the Bank of Tanzania (BoT). Indeed, the issue of how best to balance inflationary pressures associated with liquidity emanating from greater-than-projected donor aid against upward pressures on domestic interest rates and the exchange rate from increased sterilization operations, received substantial attention during program discussions with the authorities.

- In this context, the reluctance of the BoT to sterilize the impact of aid inflows through sales of foreign exchange-reflecting the implicit objective of influencing the nominal exchange rate to maintain competitiveness and ward off possible "Dutch Disease" - and relying more on either treasury bill sales (in a rather thin market for domestic debt) or on unsterilized intervention, has led to volatility in real interest rates, thereby undermining private investment and not allowing for adequate absorption of aid (Appendix 2).

\section{Against this background, Fund-supported programs adapted quite well. In} particular, policy advice, reflected inter alia in the change of the nominal anchor for monetary policy, noted correctly that competitiveness and export performance in Tanzania is largely constrained by structural factors and supply-side constraints, and that rising interest rates would have a more adverse impact on export and growth prospects than a more appreciated exchange rate. In this context, however, improvements are required concerning the appropriate measure for setting reserve money targets (and is further discussed in section IV).

\footnotetext{
${ }^{17}$ Under net domestic assets (NDA) targeting, unanticipated increases in donor financed projects could lead to excessive monetary expansion and fuel inflationary pressures, since the central bank would not be obliged to undertake sterilization operations. In contrast, reserve money targeting, which assumes full sterilization of unanticipated inflows, could cause an unwarranted tightening in the short term and an increase in interest rates if money demand is larger than anticipated or an appreciation of the exchange rate if excess liquidity is sterilized through sales of foreign exchange.
} 


\section{E. Were external and debt objectives achieved?}

\section{The objective of improving external viability was broadly achieved under the} Fund-supported programs, although the viability of the balance of payments has been largely dependent on foreign assistance. The external current account deficit as a percent of GDP was less than programmed in most years, reflecting among other things a smaller absorption of foreign aid (Figure 17). The level of gross official reserves exceeded program targets for the most part, owing to aid inflows and better than expected performance in the current account. External debt service

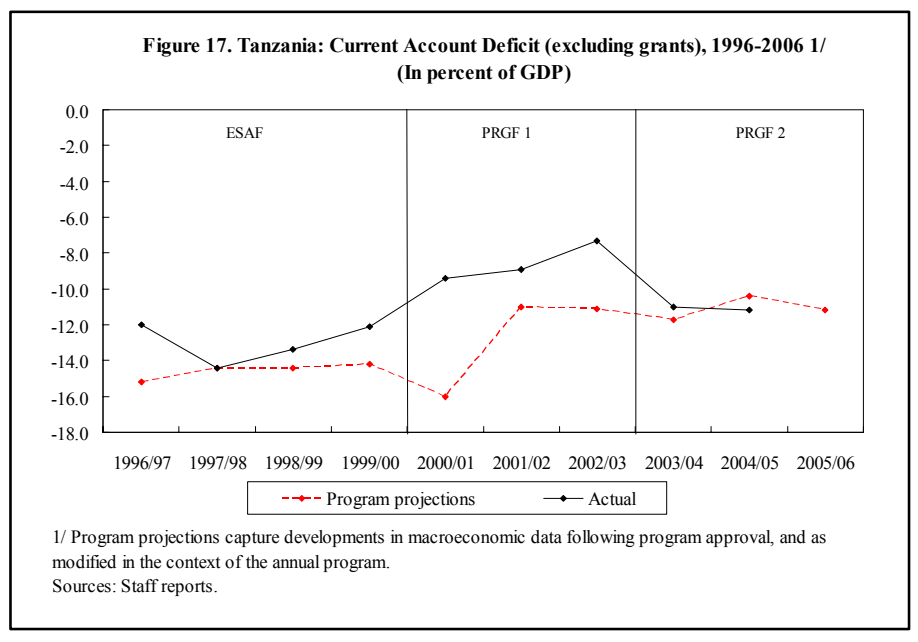
as a share of exports remained below projected debt levels, and ceilings on nonconcessional borrowings and external arrears were observed.

\section{The exchange rate while being market-determined in principle, was influenced} by the Bank of Tanzania's efforts to maintain competitiveness. Following a large appreciation of about 48 percent between 1995 and 2000, the real effective exchange rate (REER) has since depreciated by more than 35 percent, largely triggered by a 40 percent depreciation in the NEER as well as by inflation differentials with trading partners (Figure 18). As noted previously, in the context of large aid inflows, the BoT has sought to influence the exchange rate, with a view to limit any significant nominal appreciation. Recent staff studies provide empirical evidence to support

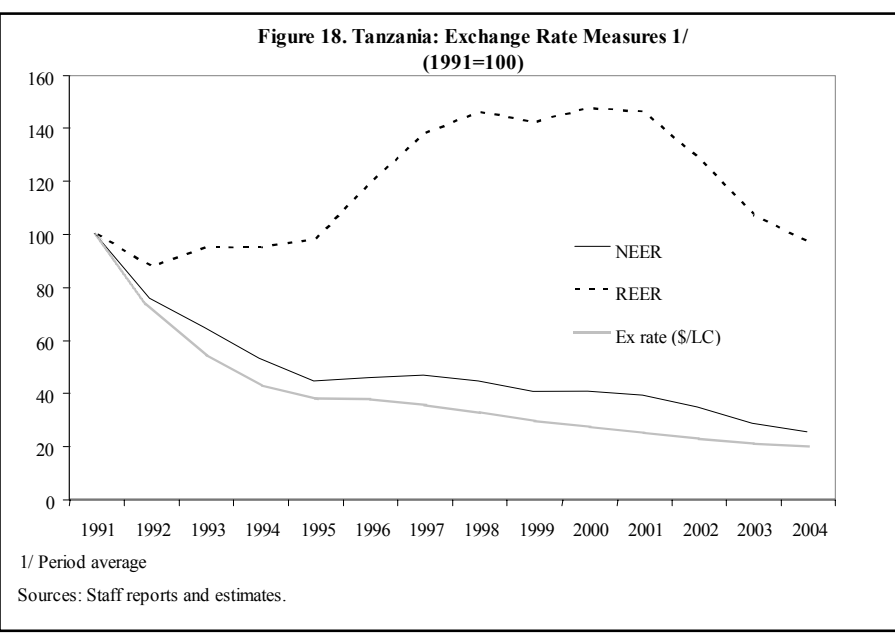
the view that the exchange rate is broadly aligned with economic fundamentals. ${ }^{18}$

\footnotetext{
${ }^{18}$ Staff analysis with data through 2001 suggested that the REER at that time may have been overvalued by about 10 percent (IMF Country Report No. 03/2). However, subsequent studies with updated data suggest no evidence of misalignment (IMF Country Report No. 04/284).
} 


\section{Export performance}

\section{Exports of goods and services have} increased in the context of Fundsupported programs. Export earnings declined over the ESAF program, reflecting largely the weather-induced decline in the output of export crops and the damage to transport infrastructure that disrupted access to external markets. In the context of PRGF1, and broadly since 2000, exports have risen, helped by ongoing trade liberalization (Figure 19). Moreover, there has been a substantial shift in composition from traditional to non-traditional exports (Figure 20). In particular, the share of nontraditional exports in total exports has risen by more than half between 1995 and 2003 . Much of the increase in the share of nontraditional exports has, however, been related to gold sales - the share of manufactured goods in total exports has actually declined relative to 1995 (Figure 21). ${ }^{19}$

\section{Notwithstanding the recent} increase in exports, their contribution to overall economic performance has been modest, and compares poorly with the region (Figure 22). In particular, the share of exports in GDP was about 17 percent in 2004, compared with around 40 percent for Sub-Saharan Africa (excluding Nigeria and South Africa). This is attributable in part to the fact that, while exchange rate competitiveness is broadly in equilibrium and the manufacturing sector is estimated to be highly responsive to real exchange rate depreciation, export performance has been hindered by various supply-side constraints, as described previously.
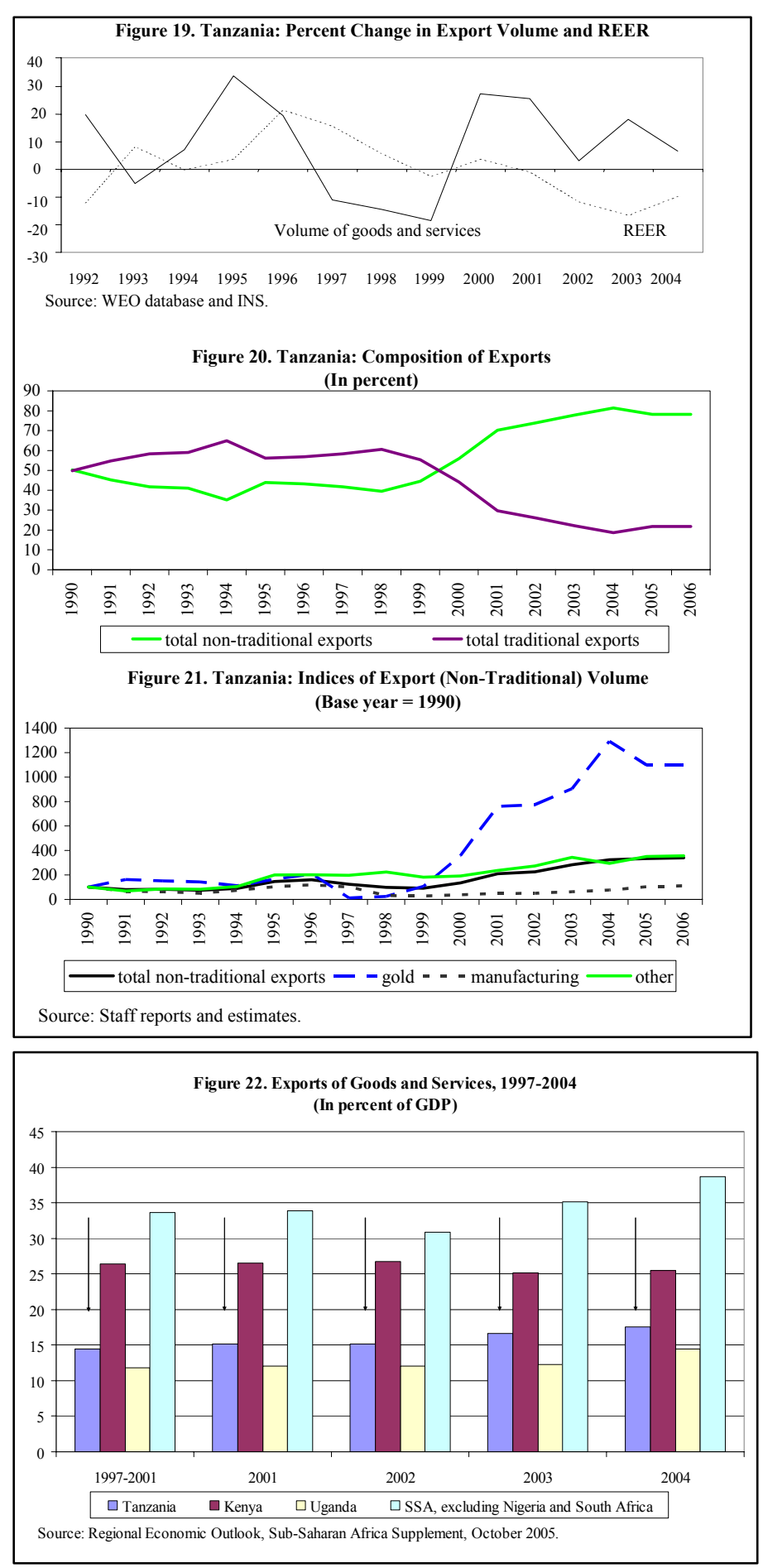

\footnotetext{
${ }^{19}$ Staff analysis suggests that there are differences in sectoral responsiveness to REER movements. In particular, for a one percent REER depreciation, manufactured exports increased by 14 percent.
} 


\section{External debt sustainability}

\section{Reaching the completion} point under the Enhanced HIPC Initiative was critical for restoring external debt sustainability in

Tanzania. Tanzania reached the completion point under the enhanced HIPC Initiative in November 2001 and has received most of the expected debt relief. Debt indicators at the HIPC completion point were significantly better than at the decision point, owing to better-thanexpected export performance.

External debt as a share of exports at end-June 2001 was reduced to 105 percent in NPV terms, bringing it to the point of debt sustainability (Figure 23). Tanzania's debt indicators have continued to further evolve favorably. Updated debt indicators (before relief under the MDRI) indicate that the NPV of debtto-exports ratio is projected to fall further, stabilizing at about 92 percent, instead of 115 percent as projected at completion point. All debt indicators remain well below indicative threshold levels.
Figure 23. Tanzania: Debt Sustainability Indicators, 2000-2010 (as a percent of exports)

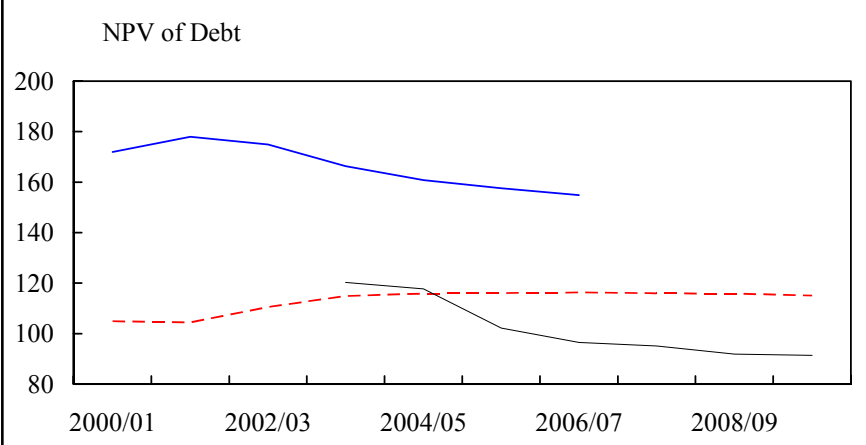

Debt Service

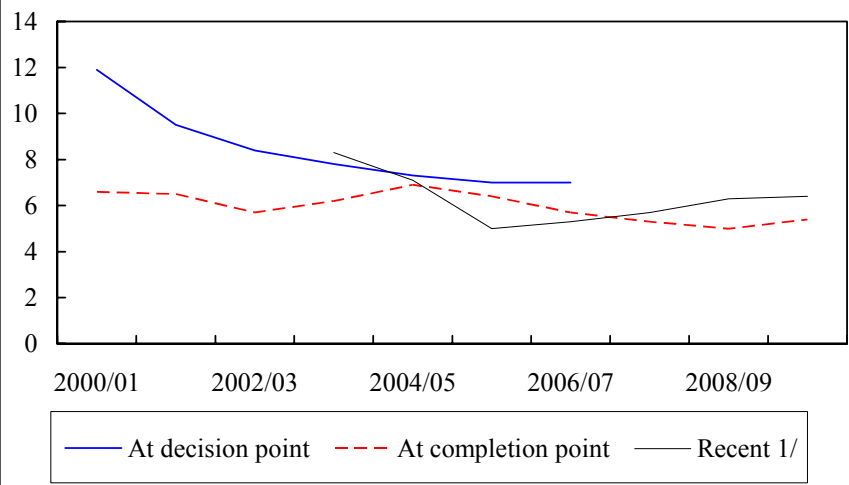

1/ Excluding debt relief under the MDRI. Sources: Staff reports and estimates.

\section{Tanzania's debt outlook has improved further following its qualification for}

debt relief under the MDRI. In particular, the NPV of debt as a share of exports is expected to decline further to about 46 percent in $2006 .{ }^{20}$ Recognizing the need for improving debt management, Tanzania adopted a National Debt Strategy (NDS) in 2002, under which the government amended the Loans, Grants, and Guarantees Act of 1974 to make contracting and guaranteeing of new foreign debt by the government (including its parastatals) subject to approval from the Minister for Finance. ${ }^{21}$ In addition, the NDS included capacity-building

\footnotetext{
${ }^{20}$ This is based on full delivery of debt relief by the Fund, the Bank, and the African Development Bank.

${ }^{21}$ Passing new debt legislation was a structural performance criterion under the program. However, given that the government changed its approach with respect to the passing of this legislation and incurred some delays, a waiver was requested under the program.
} 
initiatives and strengthened debt management through the establishment of a national debt management committee.

\section{F. Have structural reforms improved the economy's supply response?}

39. Structural reforms in Tanzania have aimed at enhancing the economy's supply response and improving economic performance.

\section{Fiscal reforms}

40. Civil service reform in Tanzania aimed at limiting the role of the civil service to priority areas and improving the efficiency of government administration. Progress in this area has been uneven. Reforms, initiated in the context of the ESAF and implemented in cooperation with the World Bank and other donors, aside from further reducing the size of the civil service, was accompanied by a major pay reform, in which most allowances were monetized and fully integrated into the wage bill along with a reduction in wage compression. Following substantial delays initially, particularly in implementing the retrenchment component, reforms eventually led to a reduction in the size of the public sector and in the wage bill as a share of GDP. Subsequently, in the context of PRGF2, the government adopted a medium-term pay strategy, with a view to enhancing the prospects for the government to recruit, retain, and motivate a critical mass of technical and professional staff. However, little was accomplished in adjusting the pay scale for this group, while critical staff in priority sectors received instead selective salary enhancements. Concurrently, a complex system of allowances - recorded outside of the wage bill — accounted for an increasing share of the total remuneration of the beneficiaries.

41. The privatization and restructuring of state-owned enterprises (SOEs) aimed at removing the burden of parastatal operations on the budget and enhancing the role of the private sector in economic activity. Building on the divestiture of more than 100 SOEs during 1992-95, the ESAF arrangement provided for the removal of at least 50 enterprises annually during 1996-98 from government control through sale, lease, liquidation, or divestiture. About two-thirds of all state-owned enterprises were privatized by end-2002. Reforms were largely successful, particularly concerning the privatization of commercial enterprises. Implementation was, however, slower than projected in the privatization of banks and the utilities, owing to technical factors in offering these enterprises for privatization or liquidation, the need for appropriate sequencing (including the establishment of appropriate regulatory frameworks), lack of coordination, and the need for elaborate consultation to achieve political consensus.

\section{Financial sector}

42. Reforms have targeted a strengthening of the financial system, with a view to enhancing its competitiveness, soundness, and contribution to investment and growth. Reforms in the context of the Fund-supported programs have included the privatization of state-owned financial institutions; improvements in the prudential and regulatory framework; and the alleviation of impediments to broad-based lending by the banks (Appendix 4). Lack 
of sufficient government commitment initially delayed reforms in the financial sector and adherence to conditionality under Fund-supported programs has varied, with privatization of state-owned banks, in particular, being characterized by significant delays.

\section{More recently, progress has been made in the implementation of the} recommendations of the joint Bank-Fund Financial Sector Assessment Program (FSAP, 2003). In particular, drawing upon the FSAP recommendations, a comprehensive Financial Sector Reform Implementation Action plan has been put together in the context of PRGF2, notably with a view to accelerating efforts aimed at removing key structural impediments to broadening access to financial services, including medium- and longer-term lending (this was a structural benchmark under PRGF2). Delays in the submission to parliament of amendments to key banking legislation, aimed at providing greater autonomy to the central bank while enhancing transparency and accountability and strengthening banking supervision, however, underscore the difficulty of reaching rapid consensus on some of these reforms. ${ }^{22}$

\section{Notwithstanding financial sector liberalization, reforms aimed at promoting} bank lending and the availability of credit, more generally, have been lackluster. Key impediments to greater bank lending to the private sector, identified by a broad spectrum of investors, include the inability to use land as collateral, underdeveloped leasing, equity and export finance markets, as well as the absence of a centralized system for credit information. In this context, significant improvements are required in effectively implementing the Land Act of 1999. Despite amendments in 2004 that addressed the issue of legal protection for lenders, a key outstanding issue that remains relates to the harmonization of the provisions of the Land Act with other laws that are related to land issues. ${ }^{23}$ These are important to the effective implementation of the Land Act. Another problem in this context concerns inadequate judicial reforms, and the role of the legal system and its inability to enforce contracts and protect bank lending. Despite the introduction of Commercial Courts in 1999 to address this anomaly, there are still problems associated with the possibility of appeals after banks receive favorable adjudication in these courts. Furthermore, capacity constraints in these courts have undermined the speedy resolution of cases and therefore the willingness of banks to engage in more broad-based lending.

\section{Under PRGF2, several initiatives were taken to facilitate access to financing,} especially for smaller or rural enterprises. These include the implementation of the National Microfinance Policy of 2000 and operationalization of the legal, regulatory and supervisory framework for microfinance; development of the Export Credit Guarantee Scheme (ECGS) which provides guarantees to commercial bank lending for crop marketing; establishment of the Small and Medium Enterprise (SME) scheme to guarantee commercial

\footnotetext{
${ }^{22}$ Structural performance criteria under PRGF2 pertaining to the submission to parliament of amendments to the Bank of Tanzania Act and the Banking and Financial Institutions Act (BFIA) were met with delays.

${ }^{23}$ These include the Land Registration Ordinance, Registration of Documents Ordinance, Town and Country Planning Ordinance, Civil Procedure Code and the Law of Marriage Act, 1971.
} 
bank credit to SMEs and of the Development Finance Guarantee Facility (DFGF) to provide credit for medium-term development finance; and the establishment of a (private) credit information bureau. ${ }^{24}$

\section{Exchange and trade reforms}

46. Exchange rate and capital account liberalization facilitated trade and foreign investment flows. Tanzania liberalized its exchange rate system in 1994 by introducing an interbank market-based foreign exchange rate, which facilitated trade related financial transactions. This and the liberalization of foreign exchange availability for making payments and transfers for current international transactions led to Tanzania accepting in the context of the ESAF program, in July 1996, the obligations under the Article VIII of the Fund's Articles of Agreement. Tanzania liberalized its capital account progressively in the context of the PRGF programs, initially by focusing on attracting foreign direct investment (FDI) and subsequently by allowing foreign portfolio investment in early 2003 .

\section{Trade liberalization promoted openness by enhancing export competitiveness} and facilitating access to lower-cost imports. Trade liberalization was achieved broadly in two phases, first in the context of Tanzania's commitments under the Cross-Border Initiative (CBI) during the ESAF program, and second, in the context of Tanzania's regional integration with the East African Community (EAC) and the Southern African Development Community (SADC) under the PRGF2 program. Most export duties were abolished under the ESAF and rationalization of import tariffs was achieved under both liberalization phases. This led to a reduction in the number of non-zero tariff rates from more than four to two, a drop in the maximum tariff from 40 to 25 percent, progress in reducing non-tariff barriers and suspended duties, as well as the adoption in 2005 of the EAC common external tariff.

48. Tanzania faces complications, however, from being a member of both the EAC and SADC, while its EAC partners are members of yet another regional trade agreement, namely the Common Market for Eastern and Southern Africa (COMESA). Such an asymmetric configuration has the potential to create confusing and conflicting situations which are bound to intensify over time as the respective integration agendas of the EAC, SADC, and COMESA deepen. In this context, Tanzania would need to ensure sufficient flexibility in its integration commitments to avoid contradictory requirements of these regional agreements which would likely arise. Above all, it is important that Tanzania anchors its regional integration efforts within a multilateral framework of liberalization, while leveraging cooperation at the regional level to tackle regulatory impediments to trade.

\footnotetext{
${ }^{24}$ The SME and DFGF schemes are in the progress of becoming actively operational. The government is further planning to establish a Long-Term Financing Facility (LTFF) and is contemplating whether to expand the activities of the state-owned Tanzanian Investment Bank to become a full-fledged development finance institution.
} 


\section{Implementation Lessons, Program Design, And Conditionality}

A. What explains the relative success of Fund-supported programs in Tanzania?

49. The success of Fund-supported programs in Tanzania reflects a combination of political will, a wide consultative process underpinning the reforms, and a good coordination of donor efforts.

\section{Political commitment and ownership}

50. Performance under the Fund-supported programs has been strong, and reflects the political will and commitment at the highest levels of the government. The relative success and durability of economic reforms in Tanzania can be attributed to a confluence of factors, including a strong and tested sense of ownership of the reforms since early in the process, a wide consensus on necessary policy actions and measures based on consultation with civil society, and consistent support from development partners. Tanzania's experience under Fund-supported programs, however, contains an element of "unevenness" in the implementation of reforms. In particular, program implementation was fairly strong concerning fiscal reforms, reflected in improvements in expenditure management, considered to be among the best in Sub-Saharan Africa, and, more recently in the context of PRGF2, in revenue performance (even though still somewhat disappointing compared to potential). At the same time, however, financial sector reforms, including the privatization of state-owned banks, have taken longer. Moreover, despite financial sector liberalization, financial intermediation remains modest, with large segments of the private sector, notably in the rural areas, having limited access to credit.

\section{PRSP Process}

\section{Strong country ownership allowed the Poverty Reduction Strategy Paper} (PRSP) to become the main instrument for coordinating the domestic poverty reduction program between the authorities and the international donor community. The first PRSP aimed at decreasing poverty by identifying priority spending areas that would benefit from additional funding, mostly health and education. To enhance its effectiveness, the PRSP was continuously updated in the annual progress reports by expanding and reprioritizing government expenditures and made increasingly responsive to local poverty problems. The approach was adjusted in the government's second-generation PRSP, the MKUKUTA, which aimed at reducing poverty through an outcome-based approach. The PRSP was built on a consultative process and helped translate the government's longer-term goals - articulated in the framework of the government's 1997 National Poverty Eradication Strategy and the government's National Development Vision 2025-into medium-term objectives anchoring the Fund-supported programs.

\section{Collaboration with the World Bank and other Donors}

52. In the context of large aid inflows, coordination between the multilateral institutions and donors has been critical to the success of reforms in Tanzania. In 
particular, the Fund has collaborated closely with the World Bank and other donors, including by providing technical assistance on areas of core expertise, but some areas have received less attention than they should have.

53. The Bank took the lead in supporting Tanzania in its reform efforts in a number of areas. This includes civil-service reform, education and health, decentralization, energy, tax administration, public enterprise reform and privatization. In improving public expenditure management, the Fund has taken the lead, with the Bank focusing on strategic resource allocation and operational efficiency of public expenditures. ${ }^{25}$ Likewise, on tax policy and administration, the Fund has taken the lead on providing advice on tax policy issues, while the Bank and other donors have led the efforts in supporting the government's efforts to enhance domestic revenue collection, including through reforms of the Tanzania Revenue Authority. Similarly, following the joint Bank-Fund FSAP in 2003, the two institutions have jointly helped the authorities formulate a reform strategy aimed at addressing the weaknesses identified by the exercise, including through technical assistance. In this context, an implementation matrix covering reforms across the various financial sectors has helped secure the buy-in of other donors. Notwithstanding the close collaboration between the Bank and the Fund, gaps have been identified in the coordination process, including in the setting of priorities for timely delivery of the Poverty and Social Impact Assessment (PSIA). ${ }^{26}$

\section{Reforms in all the above-mentioned areas were critical, but the Fund and the} Bank could have placed greater emphasis on alleviating some of the supply-side constraints (identified above) that have undermined agricultural production and exports, which is key for reducing poverty. Moreover, both institutions could have placed more emphasis on reforms aimed at improving the investment climate - including by addressing with greater urgency issues relating to the business licensing system, access to credit, and the introduction of commercial courts - with a view to facilitating investment-led growth. Similarly, notwithstanding the important role that the Bank has played in reforming the energy sector, and notably TANESCO, greater urgency could have underpinned the reforms, particularly since problems have reached crisis proportions.

55. Other donors and creditors have also been very active in Tanzania. The United Kingdom, the Netherlands, Ireland, Sweden, Norway, Germany, and others have also provided budget support tied to the PRSP. Sound macroeconomic management remains an important requirement for the donors' provision of budget support. Donors have also supported structural and institutional reforms in public expenditure management, tax administration, education and health; and assisted with capacity building. This means that

\footnotetext{
${ }^{25}$ In this context, the annual Bank-led Public Expenditure and Financial Assessment Report (PEFAR), the first of which was issued in May 2005, serves as the main instrument for the donor community to assess progress in these areas.

${ }^{26}$ Background paper to "Evaluation of the PRSP Process and Arrangements Under the PRGF," joint report by the IMF's Independent Evaluation Office and World Bank's Operations Evaluation Department, July 2004.
} 
both the Fund and the Bank would need to work closely with other donors in supporting Tanzania.

\section{B. Program Design}

56. Against the background of large macroeconomic imbalances, owing largely to fiscal profligacy, adjustment in the Fund-supported programs was appropriately anchored on strengthening fiscal performance. This meant that in addition to quantitative targets that would underpin the macroeconomic framework, programs included structural conditionality with significant focus on boosting fiscal performance. Furthermore, owing to constraints on a substantial increase in revenue, fiscal adjustment, particularly in the context of ESAF and PRGF1, was appropriately predicated on improvements in expenditure policy and management. In this context, however, strong emphasis was placed on ensuring that poverty-reducing expenditures were protected. This form of fiscal consolidation appeared to have generated the political consensus needed to achieve the stabilization goals and lay the foundation for major structural reforms.

- Program design issues concerning domestic revenue mobilization and expenditure policy and management have been discussed previously in section IIIC, and will not be repeated here.

\section{The choice of nominal anchor for monetary policy in Fund-supported programs} was sufficiently flexible in accommodating changing macroeconomic circumstances.

- Given the reliance on foreign assistance, program targets were adjusted to reflect potential volatility associated with such inflows. In particular, programs allowed for larger net domestic financing of the budget (and lower international reserve targets) if aid flows were less than expected; on the other hand, if aid inflows were larger than expected, the programs did not require a reduction in domestic financing, thereby allowing for a larger overall fiscal balance and promoting aid spending.

- The design of PRGF1 did not provide for aid absorption. In particular, given the nominal anchor for monetary policy — net domestic assets of the BoT - the central bank did not feel compelled to sterilize aid inflows through the sale of foreign exchange. This was, however, addressed in the context of PRGF2, when the nominal anchor was switched to reserve money. This succeeded in encouraging greater use of foreign exchange sales, with a view to balancing better the conflicting objectives of monetary and credit policies on the one hand and promoting external competitiveness on the other.

58. One area of concern pertaining to the setting of quantitative conditionality relates to the target for reserve money. In particular, under the Fund-supported program (PRGF2), performance criteria (PC) concerning reserve money are based on end-of-period data. On occasion, the path of reserve money within the quarter has significantly exceeded the target, only to be temporarily lowered at the end of the quarter, as the BoT withdrew liquidity on a short-term basis and provided waivers to banks to draw down their reserves below required levels. Such window-dressing operations inter alia undermine the quality and transparency of monetary policy operations and impede the development of money markets. 
While the current monetary targeting framework has served Tanzania well by providing a nominal anchor that has underpinned low inflation - the framework should be adapted to improve the liquidity management of the BOT and provide more transparency with respect to the BOT's operations. This will facilitate market development, improve the transmission of policy, and make the financial system more resilient to shocks.

\section{Conditionality and Compliance}

\section{Fiscal conditionality was predominant in all of Tanzania's Fund-supported}

programs. The three programs included altogether 156 structural conditions (prior actions, performance criteria, and benchmarks); with benchmarks constituting nearly 75 percent of all conditions (Table 3). Fiscal conditionality, primarily focusing on tax policy and administration - aimed at improving revenue mobilization - and expenditure management, accounted for nearly 44 percent of the total conditions. Moreover, fiscal reforms were supported by several quantitative targets in all three programs. The remainder of the structural conditions aimed at general economic management, the restructuring and privatization of state-owned enterprises, trade liberalization, and financial sector reform.

\section{Conditionality has generally been used to achieve key program objectives, and} there has been a reduction in both the scope and the number of conditions as programs have evolved. In particular, PRGF2 made parsimonious use of structural conditionality, limited to reforms that are critical for the achievement of macroeconomic objectives. As a result, the number of structural performance criteria declined from 61 in PRGF1 to 37 in PRGF2. Notwithstanding the streamlining, the number of structural conditions in Fundsupported programs in Tanzania was significantly greater than those in other ESAF/PRGF arrangements across the membership (Table 3).

\section{Some conditionality in Fund-supported programs has focused on longer-term} objectives, notably to ensure that rapid growth is durable. The ESAF and PRGF1 arrangements addressed a broad range of factors that affect investor sentiment and private sector activity. In the context of PRGF2, however, there was an explicit objective to enhance the economy's supply response by removing key impediments to growth and improving the investment environment. Against this background, there was a structural benchmark aimed at improving the business licensing system, which had been identified by investors as an important factor undermining private investment in Tanzania. Arguably, such reforms are not in the Fund's area of expertise, but they are key to boosting private investment and sustaining rapid growth over the medium-term.

\section{Compliance with program conditionality has improved with each program.}

During ESAF and PRGF1, most structural benchmarks and PCs were observed with delays, attributable in large part to difficulties in reaching political consensus on more contentious reforms, including privatization. This trend was, however, reversed during PRGF2, as nearly all structural benchmarks and PCs were met on time. More generally, Tanzania's compliance with conditionality has improved over time, with the number of performance criteria and structural benchmarks met on time rising (Table 4). In particular, the waiver rate of structural performance criteria declined from 60 percent under the ESAF to 31 percent under PRGF1, 
and has declined further in the context of PRGF2. Similarly, the implementation rate of structural benchmarks (including those that were met with a delay) increased from 50 percent under the ESAF to 95 percent in PRGF1 and about 100 percent in the first two years of PRGF2 (Appendix 5).

\section{Policy Challenges for the Medium-Term}

63. Sustained reforms in the context of Fund-supported programs have led to strong economic performance, but growth has not been adequate to reduce poverty significantly and aid dependency portends risks to macroeconomic stability. To make serious inroads against poverty and reduce dependence on aid gradually, Tanzania will need to sustain rapid growth for long periods of time, based on diversification and greater private sector participation in economic activity, improve domestic revenue mobilization, and alleviate structural deficiencies in the economy.

\section{Sustaining Growth and Reducing Poverty}

64. Challenges remain for Tanzania to achieve the Millennium Development Goals target for income-based poverty reduction (Table 5). The MDG income poverty target is to reduce the poverty rate by half by 2015 relative to 1990, which for Tanzania would be to reduce the poverty rate to 19.3 percent of the population. Based on statistical simulations, annual GDP and rural GDP growth for Tanzania would have to be on average about 5.1 and 4.8 percent, respectively, to achieve the MDG income poverty target, assuming no increase in income inequality and no change in the population growth rate. ${ }^{27}$ While staff projections of the average growth rate for the whole economy over the medium-term are consistent with these simulations, rural GDP growth since 1996 has been about one percentage point less than the simulated need. Similarly, simulations suggest that while the urban poverty rate is on the right path to halving the poverty rate by 2015 , the rural poverty rate remains above the path that would be needed to achieve the MDG goals.

\section{Lack of economic growth and income opportunities in the rural areas is central} to the poverty issue. The economy remains concentrated in agriculture, making it highly vulnerable to external shocks and weather patterns. Agriculture is likely to continue to have a stronghold over the near future and could constrain economic growth based on past growth patterns. To achieve the rural real GDP growth rate that will result in poverty reduction, agricultural performance has to be boosted, and resistance among interest groups to liberalize the sector needs to be overcome. In this context, further measures should focus on reforming the crop boards; improving rural infrastructure; reforming and harmonizing local government taxes; and improving access to credit. At the same time, the ability of the poor to benefit from growth could be encouraged by greater human capital development and better access to productive assets such as adoption of technology, inputs, and credit. $^{28}$

\footnotetext{
${ }^{27}$ Demombynes, G. and J.G.M. Hoogeveen, 2004.

${ }^{28}$ World Bank Group Country Assistance Strategy for Tanzania, 2000.
} 
66. Improving Export Performance. Sustaining rapid growth and reducing poverty requires a greater diversification of exports and the recovery of traditional exports, including through a further liberalization of trade. While some diversification away from traditional exports is already underway, a more broad-based export base (and not just gold) is essential. In this context, alleviating, supply-side constraints (described above) that constitute one of the major obstacles to stronger export performance, is a key challenge.

\section{Enhancing Expenditure Management and Revenue Mobilization}

\section{Improvement in public expenditure management has been a key achievement} under Fund-supported programs in Tanzania. In particular, the cash management system aimed at controlling expenditures consistent with available financing has served Tanzania well. However, it has its limitations, and going forward, expenditure management will need to rely more on improvements in liquidity forecasting, with a view to improving expenditure smoothing, based inter alia on greater coordination between monetary and fiscal policy. Similarly, while the medium-term expenditure framework has provided a good basis to align and prioritize expenditures consistent with objectives laid out in the PRSP, programs have on occasion had to accommodate expenditures not entirely consistent with these objectives. Going forward, there needs to be a greater prioritization of spending along with more accountability in decision-making.

\section{Achieving the government's growth and poverty reduction objectives makes it} imperative for Tanzania to improve domestic resource mobilization. In particular, the recent improvements in revenue mobilization should be sustained, with a view to closing the identified gap between revenue potential and outcome. This calls for continued implementation of tax administration reforms and giving serious consideration to the recommendations of the recent staff tax policy TA mission, notably concerning the further streamlining of tax exemptions and rationalizing the provision of tax incentives. ${ }^{29}$ At the same time, efforts should also be made to increase the tax base by addressing structural impediments, which would help enhance private sector participation in formal economic activity.

69. Finally, a transparent system of allocating fairly-priced concessions for the exploitation of natural resources or the use of government assets to deliver public services needs to be adopted.

\section{Improving the Management and Effectiveness of Aid}

\footnotetext{
${ }^{29}$ The recommendations include inter alia a careful review of the VAT legislation, especially with respect to its schedules - which list cases of exemption and zero-rating; eliminating the threshold on the withholding tax on interests; reinforcing the withholding tax on goods and services and increasing the base and rate for most tax excisable products, as the rates are far below those of EAC partner countries; reconsidering the Special Economic Zones (SEZs) proposal and excluding from the SEZ bill any tax incentives that are in addition to those already granted by the laws currently in effect.
} 
70. The challenges of liquidity management in the context of large aid inflows, underscore the importance of improving the coordination between monetary and fiscal policies and the supply response and absorptive capacity of the economy. In the context of a floating exchange rate regime and sustained aid inflows, persistent central bank intervention in the foreign exchange market to keep the currency from appreciating is likely to be costly. Some real appreciation is likely to be inevitable which might affect adversely exports and economic growth in the short-run. More generally, aid is effective when it is fully spent by the government and absorbed through higher net imports and an increase in the non-aid current account deficit, including through a real appreciation of the currency, preferably through the nominal exchange rate.

71. To generate growth dividends from aid, supply-side bottlenecks need to be addressed, with a view to bolstering private investment and enabling greater aid absorption. To this end, what matters is how the aid money is spent by the government. There is emerging evidence suggesting that aid inflows could increase the productivity of the tradable and non-tradable goods sectors-i.e., depending on how the aid money is used, there could be spillover effects of productivity from the non-tradable sector (for example, from public spending on infrastructure) to the tradable sector leading to export and real income growth in the medium-term. ${ }^{30}$

\section{Addressing this policy challenge requires a balancing of aid spending on social} sectors and on infrastructure and productive sectors. While social spending on health and education are critical, notably to meet some of the MDGs, the government needs to also allocate resources for infrastructure and other productive spending to mitigate the possible effects of Dutch Disease and to increase competitiveness.

\section{Enhancing the Role of the Private Sector}

73. Improving the investment climate. Improvements in the business climate are clearly needed to boost both domestic private investment and broad-based foreign direct investment. Given administrative and implementation capacity constraints, it is important to prioritize reforms in this area. This would include alleviating the prevailing regulatory hurdles, focusing in particular on further streamlining business licensing procedures; expediting customs-clearance procedures; simplifying and improving the transparency and predictability of the tax regime, including by harmonizing taxes and levies at the local government level; and facilitating and expediting access to land leases for commercial use.

74. Enhancing access to credit. Greater emphasis needs to be placed in improving broad-based access to credit.

- Reforms would need to include improvements that would allow the use of land as collateral for bank borrowing; giving renewed priority to improving the efficiency of the

\footnotetext{
${ }^{30}$ Adam, C. and D. Bevan, 2004, "Aid and the Supply Side: Public Investment, Export Performance and Dutch Disease in Low Income Countries," Department of Economics Series Ref: 201, University of Oxford.
} 
commercial courts, together with measures to strengthen corporate governance; and developing a financial leasing sub-sector that could go some way toward providing firms, particularly in the small and medium enterprises sub-sector and in rural areas that cannot currently access traditional bank lending, access to medium- to long-term financing.

- Emphasis also needs to be placed on improving the availability of medium-and long-term financing, including through broader capital market development. More generally, emphasis should be placed on improving the policy and regulatory frameworks to pave the way for greater involvement of the private sector in providing such financing and limiting government-sponsored initiatives. In this context, caution is warranted in operationalizing recent government-sponsored initiatives, including the provision of guarantees for medium- and long-term bank lending, with a view to inter alia improving governance and limiting the build-up of large contingent liabilities.

75. Improving governance. Further efforts to reduce rent seeking activities that undermine private investment and improvements in the legal system, including the elimination of backlogs in the commercial courts, would be critical for Tanzania to boost private investment, including broad-based FDI. The government also needs to guard against interventionist measures, place greater emphasis on market-based policies, and improve the efficiency in public service delivery through further civil service reforms.

\section{Energy Sector Reform}

76. The energy sector poses a serious concern for Tanzania. Tanzania is currently facing a crisis in the energy sector, and has been faced with frequent power shortages, largely attributable to delays in securing cheaper energy capacity, higher world oil prices, and weather-related disruptions. ${ }^{31}$ Greater emphasis will need to be paid in developing a mediumterm plan for the energy sector, with a view to ensuring that energy production shortfalls do not impede private sector growth and that TANESCO's financial situation does not undermine the fiscal position. In developing such a plan, the authorities will need to coordinate closely with the World Bank and other donors.

\section{STRATEgY For Future Fund InVOLVEMENT}

77. Tanzania currently has no further need for Fund financing. In the context of large aid inflows, financing has become increasingly less critical for Tanzania than the partnership role that the Fund has played in the formulation of a policy framework, first to anchor macroeconomic stability and subsequently to provide a basis for sustaining growth, reducing poverty, and improving the efficiency and competitiveness of the economy. Indeed, over the years, Fund financing for Tanzania's reform efforts has declined sharply, and the amount of resources the Fund provides is not needed to support the country's balance of payments. In contrast, donor funds cover 45 percent of public spending.

\footnotetext{
${ }^{31}$ This reflects the impact of low rainfall on the production of hydropower.
} 
78. That said, given Tanzania's growth and development challenges, there is a case for continued Fund engagement, following the expiration of the current PRGF, that goes beyond a regular surveillance relationship. In this context, the most critical role for the Fund would be to provide signals to the donor community about the appropriateness of the government's policies, rather than provide additional financing. One option would be to continue with a low-access PRGF arrangement, predicated on the assessment that while there is no clear balance of payments need, further reforms are needed over the medium-term to sustain rapid growth and alleviate poverty. The other option would be for Tanzania to seek a nonborrowing arrangement, such as a Policy Support Instrument (PSI), that would help formulate an appropriate framework of policies to sustain reforms, with a view to consolidating macroeconomic stability and debt sustainability, while deepening structural reforms in key areas that constrain growth and poverty reduction. On balance, given that Fund financing is not required for supporting the balance of payments, a PSI would be an appropriate form of Fund engagement with Tanzania over the medium-term. Whichever option is adopted, the next Fund-supported program should continue with the approach of streamlining structural conditionality, aimed at achieving key macroeconomic objectives. Given the nature of reforms that are required going forward, the World Bank and other donors will have to take the lead in a number of areas, coordinating closely with the Fund.

79. The Fund's policy dialogue with the authorities should focus on addressing the medium-term challenges identified in this report. Policy advice should be supported by Technical Assistance in the core areas of the Fund's mandate, including fiscal, monetary, and the financial sector. A strengthening of institutions in these areas, should contribute to promoting transparency and accountability in Tanzania's management of public resources. Fund TA will need to be coordinated with other partners, including the World Bank.

\section{The following are some of the priorities in the fiscal area:}

- Improving domestic revenue mobilization by broadening the tax base, including by curbing or eliminating tax exemptions, and enhancing revenue administration.

- Strengthening the linkage between MKUKUTA and the budget, and improving aid effectiveness and productivity by balancing of aid spending on social sectors and on infrastructure and productive sectors.

- Further improving Public Financial Management, particularly the budget preparation process; expanding the coverage of fiscal reporting; strengthening the National Audit Office; addressing delays in the submission of external audit reports; continuing the ongoing work on the internal audit function to make it effective; and enhancing the current procurement process.

81. The following are some of the priorities in the monetary and financial sector:

- Improving the management of aid inflows, including by coordinating fiscal and monetary policies. 
- Enhancing BoT independence, and improving liquidity management by deepening domestic debt markets, including by encouraging the establishment of collective investment vehicles, such as private pension funds.

- Increasing financial sector intermediation. A multi-pronged approach is needed to support expansion of private sector credit. This would include making use of land as collateral more effective; continuously develop the BoT's capacity to license and monitor the performance of commercial banks and nonfinancial institutions, including microfinance deposit-taking institutions.

- Promoting the availability of medium- and long-term financing and greater access to credit, particularly in rural areas.

\section{The following are some of the priorities in the external sector:}

- Eliminate remaining export restrictions; expedite duty drawbacks to reduce anti-export bias; and implement the envisaged reduction of the CET from 25 to 20 percent.

- Harmonize commitments made in integration efforts with EAC and SADC; and reduce EAC external tariffs, with a view to minimizing trade diversion.

- Alleviate behind-the-border and general supply-side constraints - this includes improving the quality of infrastructure; reduce and rationalize taxes, especially local taxes; reform crop boards; expedite customs procedures. 
Table 1. Tanzania: Macroeconomic Indicators, 1996-2004 1/ 2/

\begin{tabular}{|c|c|c|c|c|c|c|c|c|c|c|c|c|}
\hline & & Real GDP & $\mathrm{CPI}$ & Current acc & ount deficit & Gross & reserves & $\begin{array}{c}\text { Central government } \\
\text { revenue, excluding } \\
\text { grants }\end{array}$ & $\begin{array}{c}\text { Central } \\
\text { government } \\
\text { expenditure } \\
\end{array}$ & $\begin{array}{c}\text { Primary } \\
\text { balance, } \\
\text { excluding } \\
\text { grants } \\
\end{array}$ & $\begin{array}{l}\text { Overall balance, } \\
\text { excluding grants }\end{array}$ & $\begin{array}{c}\text { Overall } \\
\text { balance, } \\
\text { including } \\
\text { grants }\end{array}$ \\
\hline & & $\begin{array}{l}\text { Annual growth } \\
\text { rate }\end{array}$ & $\begin{array}{l}\text { Annual } \\
\text { average }\end{array}$ & $\begin{array}{l}\text { Excluding } \\
\text { grants }\end{array}$ & $\begin{array}{l}\text { Including } \\
\text { grants }\end{array}$ & $\begin{array}{c}\text { In millions of US } \\
\text { dollars }\end{array}$ & $\begin{array}{l}\text { In months of } \\
\text { imports of goods } \\
\text { and non-factor } \\
\text { services }\end{array}$ & In percent of GDP & $\begin{array}{c}\text { In percent of } \\
\text { GDP }\end{array}$ & $\begin{array}{c}\text { In percent of } \\
\text { GDP }\end{array}$ & $\begin{array}{c}\text { In percent of } \\
\text { GDP }\end{array}$ & $\begin{array}{c}\text { In percent of } \\
\text { GDP }\end{array}$ \\
\hline \multirow[t]{4}{*}{1996} & & & & & & & & & & & & \\
\hline & Program Approval & 5.0 & 15.0 & -15.2 & -5.7 & 313.3 & 2.3 & 15.7 & 18.2 & 0.5 & -2.4 & 0.7 \\
\hline & Annual program & 5.0 & 15.0 & -15.2 & -5.7 & 313.3 & 2.3 & 15.7 & 18.2 & 0.5 & -2.4 & 0.7 \\
\hline & Actual & 4.0 & 18.6 & -12.0 & -2.2 & 460.5 & 2.8 & 13.5 & 15.1 & 1.0 & -1.6 & 0.2 \\
\hline \multirow{4}{*}{1997} & & & & & & & & & & & & \\
\hline & Program Approval & 6.0 & 7.5 & -14.2 & -4.9 & & & 16.5 & 18.4 & 0.7 & -2.0 & 1.1 \\
\hline & Annual program & 4.7 & 13.0 & -14.4 & -4.9 & 591.7 & 2.9 & 14.2 & 17.6 & -0.9 & -3.4 & 0.5 \\
\hline & Actual & 3.8 & 14.5 & -14.4 & -6.1 & 502.5 & 2.9 & 11.9 & 14.7 & -0.6 & -2.8 & 0.2 \\
\hline \multirow{3}{*}{1998} & Program Approval & 6.0 & 5.0 & -13.3 & -4.4 & $\ldots$ & & 17.2 & 18.5 & 1.0 & -1.3 & 1.6 \\
\hline & Annual program & 4.5 & 8.0 & -14.4 & -5.1 & 712.1 & 3.7 & 13.5 & 17.6 & -2.0 & -4.1 & -1.4 \\
\hline & Actual & 4.4 & 10.4 & -13.4 & -5.1 & 599.0 & 3.2 & 11.9 & 14.7 & -1.9 & -2.8 & -0.8 \\
\hline \multirow[t]{4}{*}{1999} & & & & & & & & & & & & \\
\hline & Program Approval & 6.0 & 5.0 & -12.9 & -4.5 & $\ldots$ & & & & & 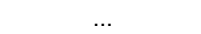 & \\
\hline & Annual program & 5.6 & 6.1 & -14.2 & -6.3 & 812.9 & 4.0 & 13.4 & 16.3 & -1.0 & -2.9 & -1.0 \\
\hline & Actual & 4.8 & 6.9 & -12.1 & -3.7 & 775.6 & 4.4 & 11.3 & 18.9 & -3.9 & -7.6 & -3.3 \\
\hline \multirow[t]{3}{*}{2000} & & 5.2 & 5.8 & -16.0 & & 853.7 & 4.2 & 11.6 & & & & \\
\hline & $\begin{array}{l}\text { Program Approval } \\
\text { Annual program }\end{array}$ & 5.2 & 5.8 & -16.0 & -4.3 & 853.7 & 4.2 & 11.6 & $\begin{array}{l}16.0 \\
16.0\end{array}$ & $\begin{array}{l}-3.1 \\
-3.1\end{array}$ & $\begin{array}{l}-4.5 \\
-4.5\end{array}$ & -0.6 \\
\hline & $\begin{array}{l}\text { Annual program } \\
\text { Actual }\end{array}$ & 4.9 & 5.9 & -9.4 & -4.4 & 9829 & 5.3 & 120 & 173 & -0.1 & $\begin{array}{l}-4.5 \\
-57\end{array}$ & -0.6 \\
\hline \multirow[t]{4}{*}{2001} & Actual & & & & & & 0.0 & 12.0 & 17.3 & -0.4 & -0.1 & -1.6 \\
\hline & Program Approval & 5.6 & 4.5 & -15.4 & -4.7 & 906.4 & 4.2 & 12.0 & 16.0 & -2.7 & -4.0 & -0.8 \\
\hline & Annual program & 5.4 & 5.0 & -11.0 & -3.5 & 950.6 & 4.6 & 11.7 & 17.2 & -4.1 & -5.5 & -1.1 \\
\hline & Actual & 5.7 & 5.2 & -8.9 & -4.8 & 1212.7 & 5.9 & 12.1 & 18.0 & -1.4 & -5.6 & -1.1 \\
\hline \multirow[t]{4}{*}{2002} & & & & & & & & & & & & \\
\hline & Program Approval & 6 & 4.0 & -14.3 & -4.2 & 1007.6 & 4.3 & 12.2 & 16.2 & -2.6 & -4.0 & -1.1 \\
\hline & Annual program & 5.5 & 4.4 & -11.1 & -3.8 & 1271.1 & 5.7 & 12.5 & 20.0 & -2.6 & -7.5 & -2.1 \\
\hline & Actual & 6.2 & 4.6 & -7.3 & -2.4 & 1670.0 & 6.6 & 12.1 & 19.8 & -2.7 & -7.8 & -1.7 \\
\hline \multirow[t]{3}{*}{2003} & Program Approval & 5.5 & 5.0 & -11.7 & -6.1 & 1818.7 & 7.0 & 12.6 & 21.1 & -3.7 & -8.5 & -3.1 \\
\hline & Annual program & 5.5 & 5.0 & -11.7 & -6.1 & 1818.7 & 7.0 & 12.6 & 21.1 & -3.7 & -8.5 & -3.1 \\
\hline & Actual & 5.7 & 4.4 & -11.0 & -5.8 & 1878.0 & 6.0 & 12.7 & 22.0 & -4.1 & -9.3 & -3.2 \\
\hline \multirow[t]{4}{*}{2004} & & & & & & & & & & & & \\
\hline & Program Approval & 6.3 & 5.0 & -10.5 & -5.2 & 1963.5 & 7.2 & 13.6 & 22.0 & -3.6 & -8.4 & -2.7 \\
\hline & Annual program & 6.3 & 5.0 & -10.4 & -4.7 & 1987.3 & 7.3 & 13.6 & 22.0 & -3.6 & -8.4 & -5.3 \\
\hline & Actual & 6.7 & 4.1 & -11.2 & -5.2 & 2137.0 & 5.9 & 13.6 & 25.0 & -5.9 & -11.4 & -4.8 \\
\hline
\end{tabular}

1/ For the ESAF arrangement, national accounts were reported on a fiscal year basis (July-June), beginning in the year indicated in the column header For the PRGF arrangements, data were reported on a calendar year basis.

2/ Data for 2000-2002 are based on the 2000-2003 PRGF arrangement, data for 2003-2006 are based on the 2003-2006 PRGF arrangement.

Source: Staff reports 
Table 2. Doing Business in Sub-Saharan Africa: Selected Countries, 2005

\begin{tabular}{|c|c|c|c|c|c|c|c|c|}
\hline & $\begin{array}{c}\text { Sub-Saharan } \\
\text { Africa }\end{array}$ & Tanzania & Kenya & Uganda & Lesotho & Mauritius & Namibia & Ghana \\
\hline \multicolumn{9}{|l|}{ Starting a Business $1 /$} \\
\hline Procedures (number) & 11 & 13 & 13 & 17 & 9 & 6 & 10 & 12 \\
\hline Time (days) & 63.8 & 35 & 54 & 36 & 92 & 46 & 95 & 81 \\
\hline \multicolumn{9}{|l|}{ Dealing with Licenses 2/ } \\
\hline Procedures (number) & 20.1 & 26 & 11 & 19 & 14 & 21 & 11 & 16 \\
\hline Time (days) & 251.8 & 313 & 170 & 155 & 265 & 132 & 169 & 127 \\
\hline \multicolumn{9}{|l|}{ Hiring and Firing Workers 3/ } \\
\hline Difficulty of Hiring Index & 48.1 & 67 & 33 & 0 & 56 & 0 & 0 & 11 \\
\hline \multicolumn{9}{|l|}{ Registering Property 4/ } \\
\hline Procedures (number) & 6.9 & 12 & 8 & 8 & 6 & 5 & 9 & 7 \\
\hline Time (days) & 117.5 & 61 & 73 & 48 & 101 & 210 & 28 & 382 \\
\hline \multicolumn{9}{|l|}{ Getting Credit 5/ } \\
\hline Legal Rights Index & 4.4 & 5 & 8 & 5 & 5 & 7 & 5 & 5 \\
\hline Credit Information Index & 1.5 & 0 & 5 & 0 & 0 & 0 & 5 & 0 \\
\hline \multicolumn{9}{|l|}{ Protecting Investors 6/ } \\
\hline Investor Protection Index & 5 & 2 & 5.3 & 5.3 & 4 & 7.7 & 6.7 & 6 \\
\hline \multicolumn{9}{|l|}{ Trading Across Borders 7/ } \\
\hline Time for Export (days) & 48.6 & 30 & 45 & 58 & $\ldots$ & 16 & 32 & 47 \\
\hline Time for Import (days) & 60.5 & 51 & 62 & 73 & 50 & 16 & 25 & 55 \\
\hline \multicolumn{9}{|l|}{ Enforcing Contracts 8 / } \\
\hline Procedures (number) & 35.9 & 21 & 25 & 15 & 49 & 17 & 31 & 23 \\
\hline Time (days) & 434.1 & 242 & 360 & 209 & 285 & 367 & 270 & 200 \\
\hline
\end{tabular}

1/ Identifies the bureaucratic and legal hurdles an entrepreneur must overcome to incorporate and register a new firm. It examines the procedures, time, and cost involved in launching a commercial or industrial firm with up to 50 employees and start-up capital of 10 times the economy's per-capita gross national income (GNI).

2/ Tracks the procedures, time, and costs to build a warehouse, including obtaining necessary licenses and permits, completing required notifications and inspections, and obtaining utility connections.

3/ Measures the flexibility of labor regulations. It examines the difficulty of hiring a new worker, rigidity of rules on expanding or contracting working hours, the non-salary costs of hiring a worker, and the difficulties and costs involved in dismissing a redundant worker.

4/ Examines the steps, time, and cost involved in registering property, assuming a standardized case of an entrepreneur who wants to purchase land and building in the largest business city—already registered and free of title dispute.

5/ Explores two sets of issues - credit information registries and the effectiveness of collateral and bankruptcy laws in facilitating lending. 6/ Measures the strength of minority shareholder protections against misuse of corporate assets by directors for their personal gain.

7/ Looks at the procedural requirements for exporting and importing a standardized cargo of goods. Every official procedure is countedfrom the contractual agreement between the 2 parties to the delivery of goods - along with the time necessary for completion.

8/ Looks at the efficiency of contract enforcement by following the evolution of a payment dispute and tracking the time, cost, and number of procedures involved from the moment the plaintiff files the lawsuit until actual payment.

Source: International Finance Corporation (www.doingbusiness.org) 
Table 3. Tanzania: Structural Conditionality, 1996-2006

\begin{tabular}{|c|c|c|c|c|c|c|c|c|c|c|c|c|c|}
\hline & \multicolumn{4}{|c|}{ ESAF 1996-1999 } & \multicolumn{4}{|c|}{ PRGF $2000-2003$} & \multicolumn{4}{|c|}{ PRGF 2003-2006 1/ } & \multirow[t]{2}{*}{ Grand Total } \\
\hline & 1st year & 2nd year & 3rd year & Total & 1st year & 2nd year & 3rd year & Total & 1st year & 2nd year & 3rd year & Total & \\
\hline Prior Actions & 0 & 0 & 0 & 0 & 0 & 3 & 0 & 3 & 2 & 0 & 0 & 2 & 5 \\
\hline Structural Performance Criteria & 3 & 3 & 4 & 10 & 3 & 5 & 5 & 13 & 6 & 4 & 1 & 11 & 34 \\
\hline Structural Benchmarks & 21 & 12 & 15 & 48 & 22 & 11 & 12 & 45 & 9 & 9 & 6 & 24 & 117 \\
\hline Total & 24 & 15 & 19 & 58 & 25 & 19 & 17 & 61 & 17 & 13 & 7 & 37 & 156 \\
\hline \multicolumn{14}{|l|}{ Of which: } \\
\hline General economic management & 6 & 1 & 3 & 10 & 4 & 2 & 1 & 7 & 3 & 3 & 3 & 9 & 26 \\
\hline Trade liberalization & 3 & 2 & 3 & 8 & 1 & 1 & 1 & 3 & 0 & 1 & 0 & 1 & 12 \\
\hline Financial sector reforms & 4 & 0 & 2 & 6 & 3 & 1 & 2 & 6 & 4 & 5 & 2 & 11 & 23 \\
\hline Tax policy and administration & 6 & 5 & 5 & 16 & 9 & 15 & 13 & 37 & 9 & 4 & 2 & 15 & 68 \\
\hline Enterprise reforms and governance & 5 & 7 & 6 & 18 & 8 & 0 & 0 & 8 & 1 & 0 & 0 & 1 & 27 \\
\hline \multicolumn{14}{|l|}{ In percent of total number of conditions } \\
\hline General economic management & 25 & 7 & 16 & 17 & 16 & 11 & 6 & 11 & 18 & 23 & 43 & 24 & 17 \\
\hline Trade liberalization & 13 & 13 & 16 & 14 & 4 & 5 & 6 & 5 & 0 & 8 & 0 & 3 & 8 \\
\hline Financial sector reforms & 17 & 0 & 11 & 10 & 12 & 5 & 12 & 10 & 24 & 38 & 29 & 30 & 15 \\
\hline Tax policy and administration & 25 & 33 & 26 & 28 & 36 & 79 & 76 & 61 & 53 & 31 & 29 & 41 & 44 \\
\hline Enterprise reforms and governance & 21 & 47 & 32 & 31 & 32 & 0 & 0 & 13 & 6 & 0 & 0 & 3 & 17 \\
\hline \multicolumn{14}{|l|}{ Memorandum item: } \\
\hline $\begin{array}{l}\text { Average number of structural condition } \\
\text { ESAF/PRGF-supported programs } 2 / \\
\text { Of which: }\end{array}$ & $\ldots$ & $\cdots$ & $\cdots$ & 33.6 & $\cdots$ & $\cdots$ & $\cdots$ & 33.6 & $\cdots$ & $\ldots$ & $\cdots$ & 15.5 & $\begin{array}{l}\ldots \\
\ldots\end{array}$ \\
\hline Prior Actions & $\ldots$ & $\ldots$ & $\ldots$ & 5.3 & $\ldots$ & $\ldots$ & $\ldots$ & 9.7 & $\ldots$ & $\ldots$ & $\ldots$ & 3.9 & $\cdots$ \\
\hline Structural Performance Criteria & $\ldots$ & $\ldots$ & $\ldots$ & 7.1 & $\ldots$ & $\ldots$ & $\ldots$ & 5.8 & $\ldots$ & $\ldots$ & $\ldots$ & 4.6 & $\ldots$ \\
\hline Structural Benchmarks & $\ldots$ & $\ldots$ & $\ldots$ & 21.1 & $\ldots$ & $\ldots$ & $\ldots$ & 189.1 & $\ldots$ & $\ldots$ & $\ldots$ & 7.0 & $\ldots$ \\
\hline
\end{tabular}

$1 / 3$ rd year of the program is not completed yet.

2/ Average conditions over the program period for ESAF- and PRGF-supported programs approved in the years 1996, 2000, and 2003. The average for the PRGF 2003-2006,

is based on reviews completed until end-2004.

Source: MONA, staff reports. 


\begin{tabular}{|c|c|c|c|c|c|c|c|c|c|c|c|c|c|}
\hline & \multicolumn{4}{|c|}{ ESAF 1996-1999 } & \multicolumn{4}{|c|}{ PRGF 2000-2003 } & \multicolumn{4}{|c|}{ PRGF 2003-2006 1/ } & \multirow[b]{2}{*}{ Grand total } \\
\hline & 1st year & 2nd year & 3rd year & Total & 1st year & 2nd year & 3rd year & Total & 1st year & 2nd year & 3rd year & Total & \\
\hline \multicolumn{14}{|l|}{ I. Quantitative performance criteria } \\
\hline Total number of criteria per year & 6 & 5 & 5 & 16 & 10 & 10 & 10 & 30 & 10 & 10 & 10 & 30 & 76 \\
\hline Of which: waived & 0 & 1 & 0 & 1 & 0 & 0 & 1 & 1 & 0 & 1 & $\ldots$ & 1 & 3 \\
\hline Waiver rate (in percent) & 0 & 20 & 0 & 6 & 0 & 0 & 10 & 3 & 0 & 10 & $\ldots$ & 3 & 4 \\
\hline \multicolumn{14}{|l|}{ II. Quantitative benchmarks } \\
\hline Total number per year & 30 & 19 & 16 & 65 & 20 & 24 & 26 & 70 & 22 & 22 & $\ldots$ & 44 & 179 \\
\hline Of which: met & 29 & 16 & 12 & 57 & 16 & 23 & 22 & 61 & 20 & $\ldots$ & $\ldots$ & 20 & 138 \\
\hline Rate of met quantitative benchmarks (in percent) & 97 & 84 & 75 & 88 & 80 & 96 & 85 & 87 & 91 & $\ldots$ & $\ldots$ & 45 & 77 \\
\hline \multicolumn{14}{|l|}{ III. Structural performance criteria } \\
\hline Total number of criteria per year & 3 & 3 & 4 & 10 & 3 & 5 & 5 & 13 & 6 & 4 & 1 & 11 & 34 \\
\hline Of which: waived & 0 & 2 & 4 & 6 & 0 & 2 & 2 & 4 & 0 & 0 & $\ldots$ & 0 & 10 \\
\hline Waiver rate (in percent) & 0 & 67 & 100 & 60 & 0 & 40 & 40 & 31 & 0 & 0 & $\ldots$ & 0 & 29 \\
\hline Waived structural performance criteria & 0 & 2 & 4 & 6 & 0 & 2 & 2 & 4 & 0 & 0 & $\ldots$ & 0 & 10 \\
\hline Implemented after delay & 0 & 2 & 3 & 5 & 0 & 2 & 1 & 3 & 0 & 0 & $\ldots$ & 0 & 8 \\
\hline offsetting measures & 0 & 0 & 0 & 0 & 0 & 0 & 1 & 1 & 1 & 0 & $\ldots$ & 1 & 2 \\
\hline Not implemented & 0 & 0 & 1 & 1 & 0 & 0 & 0 & 0 & 0 & 2 & $\ldots$ & 2 & 3 \\
\hline Implementation rate (incl. delays and offsets, in percent) & 100 & 100 & 75 & 90 & 100 & 100 & 100 & 100 & 100 & 50 & $\ldots$ & 82 & 91 \\
\hline Lapsed rate & 0 & 0 & 25 & 10 & 0 & 0 & 0 & 0 & 0 & 50 & $\ldots$ & 18 & 9 \\
\hline \multicolumn{14}{|l|}{ IV. Structural benchmarks } \\
\hline Total number of benchmarks per year & 21 & 12 & 15 & 48 & 22 & 11 & 12 & 45 & 9 & 9 & 6 & 24 & 117 \\
\hline Implemented on time & 8 & 5 & 6 & 19 & 14 & 8 & 8 & 30 & 7 & 8 & $\ldots$ & 15 & 64 \\
\hline Implemented after delay/partially met $2 /$ & 3 & 0 & 2 & 5 & 7 & 3 & 3 & 13 & 2 & 1 & $\ldots$ & 3 & 21 \\
\hline Not implemented & 10 & 7 & 7 & 24 & 1 & 0 & 1 & 2 & 0 & 0 & $\ldots$ & 0 & 26 \\
\hline Lapsed rate & 48 & 58 & 47 & 73 & 5 & 0 & 8 & 98 & 0 & 0 & $\ldots$ & 0 & 71 \\
\hline Implicit waiver rate & 14 & 0 & 13 & 27 & 32 & 27 & 25 & 2 & 22 & 11 & $\ldots$ & 0 & 29 \\
\hline \multicolumn{14}{|l|}{ V. Prior Actions } \\
\hline Total number of prior actions per year & 0 & 0 & 0 & 0 & 0 & 3 & 0 & 3 & 2 & 0 & 0 & 2 & 5 \\
\hline Total number of conditions & 60 & 39 & 40 & 139 & 55 & 53 & 53 & 161 & 49 & 45 & 17 & 111 & 411 \\
\hline Total number of performance criteria and prior actions & 9 & 8 & 9 & 26 & 13 & 18 & 15 & 46 & 18 & 14 & 11 & 43 & 115 \\
\hline Of which: met & 9 & 5 & 5 & 19 & 13 & 16 & 12 & 41 & 18 & 13 & $\ldots$ & 31 & 91 \\
\hline Total number of benchmarks & 51 & 31 & 31 & 113 & 42 & 35 & 38 & 115 & 31 & 31 & 6 & 68 & 296 \\
\hline Of which: met & 40 & 21 & 20 & 81 & 37 & 34 & 33 & 104 & 29 & 9 & $\ldots$ & 38 & 223 \\
\hline Total percentage met of performance criteria & 100 & 63 & 56 & 73 & 100 & 89 & 80 & 89 & 100 & 93 & $\ldots$ & 72 & 79 \\
\hline Total percentage met of benchmarks & 78 & 68 & 65 & 72 & 88 & 97 & 87 & 90 & 94 & 29 & $\ldots$ & 56 & 75 \\
\hline
\end{tabular}

$1 / 3$ rd year of the program is not completed yet.

$2 /$ Includes two structural benchmarks for the 1st year, "Select consultants to prepare detailed plan for unbundling TANESCO (6/30/2000)" and

"Issue implementing regulations for Public Finance Management Act and Public Audit Act (8/31/2000) ", and 1 structural benchmark for the 2nd year,

"Commence operations of the large taxpayer unit in the TRA (7/1/2001)", of 2000-2003 PRGF have been delayed with no clear status of their implementation

Source: MONA, Staff Reports. 
Table 5. Tanzania: Millennium Development Goals 1/

\begin{tabular}{|c|c|c|c|c|c|c|}
\hline & 1990 & 1994 & 1997 & 2000 & 2003 & 2004 \\
\hline 1 Eradicate extreme poverty and hunger & \multicolumn{6}{|c|}{2015 target $=$ halve $1990 \$ 1$ a day poverty and malnutrition } \\
\hline Percentage share of income or consumption held by poorest $20 \%$ & 2.4 &.. &.. & .. & .. & .. \\
\hline Population below $\$ 1$ a day $(\%)$ & 48.5 & .. & .. & .. & .. & .. \\
\hline Population below minimum level of dietary energy consumption $(\%)$ &.. & .. & 50 & .. & 44 & .. \\
\hline Poverty gap ratio at $\$ 1$ a day (incidence $\mathrm{x}$ depth of poverty) & 24.4 & .. & .. & .. & .. & .. \\
\hline Poverty headcount, national (\% of population) & 38.6 & .. & .. & 35.7 & .. & .. \\
\hline Prevalence of underweight in children (under five years of age) & .. & .. & 30.6 & 29.4 & .. & .. \\
\hline Net primary enrollment ratio (\% of relevant age group) & 49.6 & .. & 45.8 & 49.8 & 68.8 & .. \\
\hline Primary completion rate, total (\% of relevant age group) & 62 & 57.4 & 57.5 & 48.6 & 57.7 & 57.7 \\
\hline Proportion of pupils starting grade 1 who reach grade 5 & 78.8 &.. & 80.9 & 81.4 & 82 & .. \\
\hline Youth literacy rate (\% ages $15-24)$ & .. &.. & .. & .. & 78.4 & .. \\
\hline 3 Promote gender equality & \multicolumn{6}{|c|}{2015 target $=$ education ratio to 100} \\
\hline Ratio of girls to boys in primary and secondary education $(\%)$ & 95.5 & .. & 98.2 & 98.8 &.. & .. \\
\hline Ratio of young literate females to males (\% ages $15-24)$ & .. & .. &.. &.. & 94.2 & .. \\
\hline 4 Reduce child mortality & \multicolumn{6}{|c|}{2015 target $=$ reduce 1990 under 5 mortality by two-thirds } \\
\hline Immunization, measles ( $\%$ of children ages $12-23$ months) & 80 & 79 & 73 & 78 & 97 & 97 \\
\hline Infant mortality rate (per 1,000 live births) & 102 & 103 &.. & 104 & 104 & 104 \\
\hline Under 5 mortality rate (per 1,000 ) & 163 & 164 & .. & 165 & 165 & 165 \\
\hline 5 Improve maternal health & \multicolumn{6}{|c|}{2015 target $=$ reduce 1990 maternal mortality by three-fourths } \\
\hline Births attended by skilled health staff ( $\%$ of total) &.. &.. & 38.2 & 35.8 & .. & .. \\
\hline Maternal mortality ratio (modeled estimate, per 100,000 live births) &.. &.. & .. & 1500 & .. & .. \\
\hline 6 Combat HIV/AIDS, malaria, and other diseases & \multicolumn{6}{|c|}{2015 target $=$ halt, and begin to reverse, AIDS and other major } \\
\hline Contraceptive prevalence rate (\% of women ages $15-49)$ & 9.5 &.. & 18.4 & 25.4 & .. & .. \\
\hline Incidence of tuberculosis (per 100,000 people) & 183.5 & 254.6 & 313.8 & 347.5 & 371.2 & 371.2 \\
\hline Number of children orphaned by HIV/AIDS & .. & .. &.. & 790000 & 980000 & 980000 \\
\hline Prevalence of HIV, total (\% of population aged $15-49)$ & .. & .. & .. & 9 & 8.8 & 8.8 \\
\hline Tuberculosis cases detected under DOTS (\%) &.. & 55 & 50.8 & 46.8 & 42.8 & 42.8 \\
\hline 7 Ensure environmental sustainability & \multicolumn{6}{|c|}{2015 target $=$ various } \\
\hline Access to an improved water source ( $\%$ of population) & 38 & .. &.. & .. & 73 & .. \\
\hline Access to improved sanitation (\% of population) & 47 & .. &.. & .. & 46 & .. \\
\hline Forest area ( $\%$ of total land area) & 45 &.. & .. & 43.9 & .. & .. \\
\hline GDP per unit of energy use (2000 PPP \$ per kg oil equivalent) & 1.4 & 1.3 & 1.4 & 1.3 & 1.4 & .. \\
\hline Nationally protected areas (\% of total land area) &.. & .. & .. & .. & 29.8 & 29.8 \\
\hline 8 Develop a global partnership for development & \multicolumn{6}{|c|}{2015 target $=$ various } \\
\hline Aid per capita (current US\$) & 46.1 & 33.5 & 30.2 & 30.3 & 46.5 & 46.5 \\
\hline Debt service (\% of exports) & 31 & 18 & 13 & 12 & 6 & 6 \\
\hline Fixed line and mobile phone subscribers (per 1,000 people) & 3.1 & 3.2 & 4.2 & 10.8 & 29.5 & 29.5 \\
\hline Internet users (per 1,000 people) & .. &.. & 0.1 & 1.2 & 7.1 & 7.1 \\
\hline Personal computers (per 1,000 people) & .. & .. & 1.7 & 3.1 & 5.7 & 5.7 \\
\hline Unemployment, youth female (\% of female labor force ages $15-24$ ) &.. & .. &.. &.. & .. & .. \\
\hline Unemployment, youth male (\% of male labor force ages $15-24)$ &.. & .. &.. & .. & .. & .. \\
\hline Unemployment, youth total (\% of total labor force ages $15-24)$ &.. &.. &.. &.. &.. & .. \\
\hline \multicolumn{7}{|l|}{ Other } \\
\hline Fertility rate, total (births per woman) & 6.3 & 5.8 & 5.6 & .. & 5 & 5 \\
\hline GNI per capita, Atlas method (current US\$) & 200 & 170 & 230 & 280 & 310 & 330 \\
\hline GNI, Atlas method (current US\$) (billions) & 4.8 & 4.5 & 6.6 & 8.9 & 10.7 & 11.6 \\
\hline Gross capital formation ( $\%$ of GDP) & 26.1 & 24.6 & 14.9 & 17.6 & 18.6 & 19.2 \\
\hline Life expectancy at birth, total (years) & 50.1 & .. & 47.9 & 45 & 42.7 & 42.7 \\
\hline Literacy rate, adult total ( $\%$ of people ages 15 and above) & .. & .. & .. & .. & 69.4 & .. \\
\hline Population, total (millions) & 25.5 & 28.8 & 31.3 & 33.7 & 35.9 & 36.6 \\
\hline Trade (\% of GDP) & 50.1 & 64.2 & 43.1 & 37.1 & 45.6 & 45.6 \\
\hline
\end{tabular}

1/ Figures in italics refer to periods other than those specified.

Source: World Development Indicators database, April 2005 


\section{Appendix 1. Reforms Aimed at Private Sector Development}

Reforms were aimed at addressing factors identified by investors as undermining the investment climate.

- A simplified business licensing system was adopted. Under the business licensing reform, license fees were reduced, and abolished for small businesses; expected time to obtain a license was reduced to 2 days; and one-stop licensing centers were established. The licensing system was transformed from a revenue raising into a mere informational tool. Draft bills on Business Activities Registration and Reform of the Regulatory Licensing System are expected to be submitted to parliament in 2006.

- Efforts were made to privatize utilities, with a view to improving the quality of infrastructure. Disengagement of the government from the water and energy utilities was aimed at helping improve service delivery. ${ }^{32}$ Similarly, a Road Fund was established aimed at improving the quality of the road network.

- A review of labor laws was undertaken, and the first phase of the Labor Law Reform was approved, addressing employment relations, collective labor relations, dispute resolutions and labor market institutions.

- In the context of the Agricultural Sector Development Program, adopted in 2001, and the Rural Development program, a review of the crop boards was undertaken, with a view to end state involvement in procurement and marketing and to limit their role to regulation, and agricultural taxation and other taxes at the local government level were harmonized and simplified.

The Commercial Dispute Resolution (CDR) component of the BEST was established and capacity of commercial courts enhanced, with a view to keep average case resolution below 6 months and ensure efficient and expedient resolution of court cases.

\footnotetext{
${ }^{32}$ The electricity company is operating under a management contract. However, the telecommunications company was not effectively privatized. While a minority stake was sold to a foreign investor, the sale was contested and the subject of a protracted legal dispute. The government is now acting as the majority shareholder.
} 


\section{Appendix 2. Tanzania's Experience With Managing Aid Flows ${ }^{1}$}

The surge in net aid inflows to Tanzania since the late 1990s has created challenges for macroeconomic management. Net aid inflows have more than doubled between 1997/98 to 2003/04 as a share of GDP. Coordination between fiscal, monetary, and exchange rate policies becomes critical for successful management of aid flows. When aid is "spent," it leads to a widening of the non-aid-related fiscal deficit; when aid is "absorbed," imports rise causing a widening of the non-aid-related current account deficit. Full absorption and spending is the textbook response to aid flows, but given the rather mixed evidence on the impact of aid on economic growth, caution is necessary owing to the adverse effects that might arise from a real appreciation of the currency (the "Dutch Disease"). ${ }^{2}$

Tanzania: Aid Inflows

(in percent of GDP)

\begin{tabular}{llllllll}
\hline & $1997 / 98$ & $1998 / 99$ & $1999 / 2000$ & $2000 / 01$ & $2001 / 02$ & $2002 / 03$ & $2003 / 04$ \\
\hline Net aid inflows 1/ & 4.6 & 6.6 & 7.5 & 7.9 & 6.6 & 7.6 & 9.4 \\
Gross aid inflows & 13.3 & 12.7 & 12.8 & 12.5 & 10.5 & 10.5 & 12.1 \\
\hline
\end{tabular}

$1 /$ Net aid $=$ gross aid + debt relief (incl. HIPC relief) - debt service + arrears accumulation.

Tanzania has fully spent the aid flows, but absorption has been slow.

Fiscal response: The aid inflows were channeled through the budget to finance greater public expenditures, resulting in an increase in the non-aidrelated fiscal deficit, suggesting that the aid money was spent by the government. Indeed, capital expenditures were correlated with net aid inflows.

Monetary response: If aid is fully spent and absorbed, there is no effect on the money supply. However, if spending exceeds absorption - as it did in Tanzania from around 1999 to mid-2003 - monetary policy must contend with a rise in domestic liquidity. During 1999/2000, worried about price stability, the BoT sterilized the impact of large aid inflows through sales of treasury bill. As a result, however, interest rates remained high and crowded out the private sector. During 2000/01 through 2002/03, as inflation declined, the BoT became concerned about the cost of sterilization, and allowed the money supply to expand. Since mid-2003, the monetary response has shifted more toward aid absorption. The BoT complemented the sale of domestic securities with the sale of foreign exchange to dampen the liquidity pressures arising from the aid-related flows. Such foreign exchange sales had been previously avoided for fears of currency appreciation. As a result, the non-aid-related current account deficit increased, reflecting greater aid absorption.

\begin{tabular}{|c|c|c|c|c|c|c|c|}
\hline & 1998 & 1999 & 2000 & 2001 & 2002 & 2003 & 2004 \\
\hline \multicolumn{8}{|l|}{ Real sector 1/ } \\
\hline GDP growth & 3.7 & 3.5 & 5.1 & 6.2 & 7.2 & 7.1 & 6.7 \\
\hline Per capita income (US\$) & 260 & 266 & 270 & 2740 & 277 & 285 & 308 \\
\hline Private investment growth & 27.3 & 11.6 & 5.4 & 12.1 & 15.6 & 10.1 & 13.8 \\
\hline CPI Inflation & 13.2 & 9.0 & 6.2 & 5.2 & 4.6 & 4.5 & 4.3 \\
\hline \multicolumn{8}{|l|}{ Monetary sector 1/ } \\
\hline M3 growth & 10.8 & 18.6 & 14.8 & 17.1 & 25.1 & 16.6 & 19.2 \\
\hline Reserve money growth & 14.7 & 21.5 & 9.4 & 5.0 & 19.1 & 12.6 & 23.5 \\
\hline Claims on private sector 1 / & 43.8 & 26 & 10.3 & 21.1 & 41.4 & 43.2 & 29.7 \\
\hline 91-day T-bill rate (avg.) & 11.8 & 10.1 & 9.8 & 4.1 & 3.6 & 6.3 & 8.4 \\
\hline Discount rate & 17.6 & 20.2 & 10.7 & 8.7 & 9.2 & 12.3 & 14.4 \\
\hline \multicolumn{8}{|l|}{ Fiscal indicators } \\
\hline Fiscal bal. (\% of GDP) & -0.6 & -1.4 & -2.6 & -1.2 & -1.0 & -1.4 & -3.0 \\
\hline \multicolumn{8}{|l|}{ External indicators 1/ } \\
\hline Curr. acc. bal. (\% of GDP) & -11.0 & -9.9 & -5.3 & -4.7 & -3.8 & -2.4 & -5.5 \\
\hline Reserves (bill. of US\$) & 0.6 & 0.8 & 1.0 & 1.2 & 1.5 & 2.0 & 2.3 \\
\hline In months of imports & 2.9 & 4.2 & 5.3 & 6.1 & 7.8 & 9.0 & 8.2 \\
\hline REER change 2/ & 5.7 & -2.5 & 3.7 & -1.0 & -11.8 & -16.6 & -9.8 \\
\hline Export volume growth & -14.5 & -18.5 & 27.5 & 25.6 & 3.2 & 18.2 & 6.7 \\
\hline
\end{tabular}

\section{There is no evidence of "Dutch Disease" in Tanzania.}

Notwithstanding the modest real appreciation of the exchange rate in 2000, the policy response during the period 2000/01 to 2002/03 resulted in a cumulative depreciation in the real effective exchange rate of about 40 percent during 2001 to 2004 . While staff studies suggest that the real exchange rate is broadly in equilibrium, structural issues continue to impede the country's external competitiveness and export performance. ${ }^{3}$

\footnotetext{
${ }^{1}$ Tanzania was a case study in the IMF B oard Paper "The Macroeconomic of Managing Increased Aid Inflows: Experiences of Low-Income Countries and Policy Implications," (www.imf.org).

${ }^{2}$ The term refers to the harmful effect resulting from large foreign exchange inflows on external competitiveness of other export sectors (such as manufactured goods).

${ }^{3}$ See IMF Country Report No. 04/284 for a discussion of Tanzania's equilibrium exchange rate.
} 


\section{Appendix 3. Key Fiscal Reforms under Fund-supported Programs}

\section{ESAF}

- Introduction of the Value Added Tax (VAT).

- Liberalization of petroleum product pricing and importation.

- Unification of the withholding tax on interest earnings, dividends, and royalties for holders and non-holders of Tanzania Investment Certificates.

- Streamlining of tariff exemptions for capital goods imports through the adoption of a tariff classification based on the Harmonized System of Customs Classification.

- Strengthening tax administration through the establishment of the Tanzania Revenue Authority; revisions to the investment act to eliminate tax holidays

- Restructuring and privatization of a number of government-owned public enterprises.

- Introduction of civil service reforms.

- Preparation of comprehensive monthly expenditure commitment monitoring flash reports, with a view toward eliminating domestic arrears - this laid the foundation for the eventual introduction of the Integrated Financial Management System (IFMS).

\section{PRGFI}

- Adoption by the Tanzania Revenue Authority (TRA) of a corporate plan, which underpins the on-going tax administration reforms.

- The introduction of VAT on petroleum products combined with a simplification of other petroleum taxes.

- Commencement of the operation of the Large Taxpayers' Department (LTD).

- Enactment of the Public Finance Management Bill and Public Audit Bill, aimed at providing the legal basis for the conduct of public financial management.

- Introduction of a systematic reconciliation of all government bank accounts.

\section{PRGF2}

- Pursuit of a modernization strategy by the TRA, which includes an expanded coverage of the LTD; integration of the VAT and income tax departments; and efforts to reduce exemptions.

- Introduction of a new Income Tax Act and an increase in the threshold for the VAT, with a view to ease administration.

- Introduction of a computerized risk management system aimed at expediting customs clearance.

- Amendment to the Tanzania Investment Act limiting the applicability of fiscal stability clauses to 5 years.

- Introduction of the Treasury Voucher system to curtain the abuse of existing exemptions.

- Introduction of guidelines to local councils for the harmonization of taxes, levies, and licenses. 


\section{Appendix 4. Financial Sector Reforms under the Fund-Supported Programs}

Financial sector reforms in Tanzania have been underway since 1992, following a legacy of state-ownership of the banking system and the monopoly status of the National Bank of Commerce (NBC). At the inception of economic reforms in 1986, financial policies had been designed to control interest rates and direct credit to borrowers considered high priority by the government. The public sector played a dominant role in the allocation of credit - with the parastatal sector having automatic access to credit from the state-owned banks, which in turn had automatic access to liquidity from the Bank of Tanzania. The bulk of NBC's lending was to the loss-making parastatal sector.

- Efforts to strengthen the financial sector began in the context of the ESAF arrangement with the restructuring and recapitalization of the National Bank of Commerce in 1997, which was split in two - the National Bank of Commerce (NBC) and the National Microfinance Bank (NMB). This was preceded by the restructuring and full privatization of the Cooperative and Rural Development Bank (CRDB) in 1996. Plans to restructure the People's Bank of Zanzibar (PBZ) have continued to remain unexecuted.

- These were followed by further reforms in the context of PRGF1, including the adoption of a microfinance policy and a revision of prudential regulations, aimed at diversifying and strengthening the financial sector.

- Drawing upon the recommendations of the Financial Sector Assessment Program (FSAP) conducted in 2003, the authorities have developed and adopted in the context of PRGF2 an implementation plan - the Second Generation Financial Sector Reforms - which has broad ownership. ${ }^{33}$ To support the reform agenda, Tanzania has embarked on the review of financial sector legislation and regulations. Other reforms in the context of PRGF2 include the adoption of an action plan to reform and simplify the business licensing system, the introduction of short-term collateralized Lombard Facility, and Government approval and announcement of preferred bidder for NMB (it was partially privatized resulting in 49 percent of its shares in private hands).

\footnotetext{
${ }^{33}$ Finalization and submission of the plan to government was a structural benchmark under PRGF2.
} 
Appendix 5. Compliance with Structural Conditionality Performance, 1996-2006

\begin{tabular}{|c|c|c|c|c|c|}
\hline \multicolumn{2}{|l|}{ ESAF 1996-1999 } & \multicolumn{2}{|l|}{ PRGF 2000-2003 } & \multicolumn{2}{|l|}{ PRGF 2003-2006 1/ } \\
\hline Condition & Status & Condition & Status & Condition & Status \\
\hline \multicolumn{6}{|c|}{ Prior Actions } \\
\hline & & $\begin{array}{l}\text { A first inventory of domestic arrears accumulated up } \\
\text { to end-December 2000, including those of Ministry of } \\
\text { Defense. }\end{array}$ & Met & $\begin{array}{l}\text { Adoption by the Tanzania Revenue Authority } \\
\text { (TRA) board of corporate plan }\end{array}$ & Met \\
\hline & & $\begin{array}{l}\text { Integrated Financial Management System (IFMS) } \\
\text { included all central government budgetary votes. }\end{array}$ & Met & Submission to Parliament of a new income tax act & Met \\
\hline & & $\begin{array}{l}\text { Clearing all remaining budgetary arrears to } \\
\text { TANESCO. }\end{array}$ & Met & & \\
\hline \multicolumn{6}{|c|}{ Performance Criteria } \\
\hline $\begin{array}{l}\text { Approve and provide terms of reference to short list of } \\
\text { firms for review of NBC restructuring. }\end{array}$ & Met & $\begin{array}{l}\text { Select winning bidder for TTCL and begin final } \\
\text { negotiations. }\end{array}$ & Met & $\begin{array}{l}\text { Submit to Parliament amendments to the Bank of } \\
\text { Tanzania Act and the Banking and Financial } \\
\text { Institutions Act. }\end{array}$ & Waived \\
\hline $\begin{array}{l}\text { Distribute taxpayer registration forms and assign tax ID } \\
\text { numbers. }\end{array}$ & Met & $\begin{array}{l}\text { Submit Public Finance Management Bill and Public } \\
\text { Audit Bill to Parliament }(6 / 00) \text {. }\end{array}$ & Met & $\begin{array}{l}\text { Submit to Parliament amendments to the Bank of } \\
\text { Tanzania Act and the Banking and Financial } \\
\text { Institutions Act. }\end{array}$ & Waived \\
\hline Retrenchment of further 10,000 civil servants. & Not met & $\begin{array}{l}\text { Unify the withholding tax on interest earnings, } \\
\text { dividends and royalties for holders and nonholders of } \\
\text { TIC certificates. }\end{array}$ & Met & $\begin{array}{l}\text { Limit Government guarantees under the three } \\
\text { medium-term credit facilities as described in } \\
\text { paragraphs } 42-44 \text { of the MEFP. }\end{array}$ & $\mathrm{N} / \mathrm{A}$ \\
\hline Remove controls on petroleum product prices. & Waived & $\begin{array}{l}\text { Complete verification and auditing of all budgetary } \\
\text { arrears by external auditor. }\end{array}$ & Waived & $\begin{array}{l}\text { Submission to parliament of amendments to the } \\
\text { Land Act }\end{array}$ & Met \\
\hline $\begin{array}{l}\text { Pending removal of controls, increase price ceilings in } \\
\text { line with import costs and refrain from reductions in } \\
\text { ceilings (continuous). }\end{array}$ & Waived & $\begin{array}{l}\text { Complete the reconciliation of the balances of all } \\
\text { Government accounts at the Bank of Tanzania as at } \\
\text { June } 30,2000 \text {. }\end{array}$ & Met & $\begin{array}{l}\text { Government approval and announcement of } \\
\text { preferred bidder for National Microfinance Bank } \\
\text { (NMB). }\end{array}$ & Met \\
\hline $\begin{array}{l}25 \text { additional enterprises to be removed from } \\
\text { government control. }\end{array}$ & Met & $\begin{array}{l}\text { Complete the reconciliation of the balances of all } \\
\text { Government accounts in commercial banks as at } \\
\text { June } 30,2000 \text {. }\end{array}$ & Met & $\begin{array}{l}\text { Issue final bid instructions for the sale of the } \\
\text { National Microfinance Bank (NMB). }\end{array}$ & Met \\
\hline Issue open invitations to bid for NBC subsidiaries. & Waived & $\begin{array}{l}\text { Clear all audited arrears outstanding at end-June } \\
2000 .\end{array}$ & Waived & $\begin{array}{l}\text { Announcement of revision of the value-added tax } \\
\text { (VAT) threshold to reduce the number of VAT } \\
\text { taxpayers, together with the abolition of remaining } \\
\text { stamp duties on receipts, and revision of the } \\
\text { threshold for the presumptive tax accordingly }\end{array}$ & Met \\
\hline
\end{tabular}


Complete technical study on options for divestiture of Waived oil refinery.

\section{Issue invitation to bid for Tanzania}

Telecommunications Co. (2/28/99).

Cabinet decision on TIPER divestiture strategy, including provision for closing the refinery by $11 / 99$, if a private buyer prepared to operate it as a refinery has not been identified by $6 / 99$.
Begin publishing quarterly budget execution reports drawn from the IMFS starting with a report for the first quarter of 2001/02 (July-June).

Waived Clear all audited domestic arrears accumulated during the period July-December 2000.

Waived Submit to Parliament legislation that makes the government's incurring or guaranteeing of foreign debt subject to cabinet approval upon

recommendation by the Minister of Finance.

Identify the budgetary codes for priority expenditures and apply them in the budget guidelines for 2003/04.

Submit to parliament amendments to the Loans, Guarantees, and Grants Act.

Announce timetable for the elimination of the suspended duties (import surcharges) imposed in the budget for 2001/02 on 13 product groups.

\section{Structural Benchmarks}

Institute book-entry system for government securities.

Analyze monthly reports from the NBC (1997) and the $\mathrm{NMB}$ on their compliance with their memoranda of understanding and issue instructions for any necessary corrective actions (monthly)

Restructuring plan for PBZ.

Split NBC into 3 banks (trade, regional and microfinance).

Issue investment memo to potential investors in the NBC.

Met

Final consideration by Parliament of the new Income Tax Act

Submission to parliament of the new income tax law, to become effective $1 / 1 / 2004$

Waived Establishment of an interagency, interministerial financial sector reform committee to oversee FSAP reform agenda

Publicizing of the list of companies, individuals, and NGO's that have received tax exemptions each quarter, as specified in paragraph 42 of the letter of intent.

Met

Adopt microfinance policy.

Issue 10 revised prudential regulations: 5 regulations

Adoption of an action plan to reform and simplify the business licensing system

Finalize and submit to government the Financial Sector Reform Implementation Action Plan.

Met with remainder.

Met

Inter-agency committee on financial sector reform will submit to government a proposed unified legal and regulatory framework for all pension funds, and investment guidelines, as described in paragraph 46 of the MEFP.

Establish conditions for the use of land as collateral Partially me for bank loans.

Introduction of short-term collateralized Lombard facility

Not met Harmonize the treatment of loan loss provisions by banks for prudential requirements and taxation purposes.
No met Review of prudential regulations, as indicated in the paragraph 32 of LOI. delay

$\mathrm{N} / \mathrm{A}$ 


\section{ESAF 1996-1999}

PRGF 2000-2003

PRGF 2003-2006 1/

\begin{tabular}{ll}
\hline Condition & Status \\
\hline
\end{tabular}

Complete VAT analysis and decide threshold.

Met

Submit to parliament the draft law establishing the legal, regulatory, and supervisory framework for microfinance operations.

Institute manual processing if VAT computer system not functional.

Complete primary school mapping in $50 \%$ of district authorities.

Increase percentage of children under 2 years immunized (measles and DPT) from $71 \%$ to $75 \%$. in 10 key ministries.

VAT legislation to be passed by parliament

Not met

Complete household budgetary survey.

Met

Ensure adequate funding for the preparation of a core set of macroeconomic statistics by the NBS in the budget for 2001/02.

equipment, and communication for intro of VAT.

Installation of VAT computerization

Not met

Submit new statistics law to parliament.

Met

Publish second report on the implementation of the ministerial anticorruption plans.

Eliminate earmarking of any petroleum revenues for TPDC. arrangements.
Status

Condition

Status

Met

Submit to parliament an amendment of the

Tanzania Investment Act, to limit the applicability

of fiscal stability clauses to at most 5 years.
Met with

Met

Complete the quality assurance review of the Customs and Excise Department reforms under the TRA's second corporate plan, including an updating of the action plan focusing on postclearance auditing and compliance.

Expand the coverage of the Large Taxpayer Department to 250 taxpayers.

Implementation of a function-based Large Taxpayers Department that integrates VAT and income tax administration, and completion of transfer of an additional 100 large taxpayers to the LTD

Met with Increase the number of staff in the post-

delay clearance audit section of customs to 32 as described in paragraph 27 of MEFP.

Integrate the destination inspection program with customs procedures at all customs offices in the Dar es Salaam region as described in paragraph 27 of MEFP.

Large Taxpayer Department to introduce collection of income tax based on selfassessment

Promulgate the implementing regulations for the new Income Tax Act, consistent with paragraph 26 of the LOI.

Met

Revision of the value-added tax (VAT) threshold to substantially reduce the number of VAT presumptive tax accordingly taxpayers, and revision of the threshold for the
Met

Met 
Complete extension of commitment monitoring system to all ministries.

To curtail tax exemptions, no new companies will Partially met be added to the list of strategic investors

maintained by the Tanzania Investment Center,

and no companies will be licensed for the export processing zone

Delayed To curtail tax exemptions, no new companies will Partially met To curtail tax exemptions, no new companies be added to the list of strategic investors maintained by the Tanzania Investment Center,
and no companies will be licensed for the export processing zone

The government will ensure that the instruments establishing the Development Finance Guarantee Facility and Development Finance Institution require an annual independent operational audit to verify that the funds are being used for the purposes intended a 


\begin{tabular}{|c|c|c|c|c|c|}
\hline \multicolumn{2}{|l|}{ ESAF 1996-1999 } & \multicolumn{2}{|l|}{ PRGF 2000-2003 } & \multicolumn{2}{|l|}{ PRGF 2003-2006 1/ } \\
\hline Condition & Status & Condition & Status & Condition & Status \\
\hline $\begin{array}{l}\text { Publish BOP statistics according to 5th manual } \\
\text { method. }\end{array}$ & Met & $\begin{array}{l}\text { Issue implementing regulations for Public Finance } \\
\text { Management Act and Public Audit Act. }\end{array}$ & Delayed & $\begin{array}{l}\text { Publish the list of companies, individuals, and } \\
\text { NGO's that have received tax exemptions each } \\
\text { quarter under the Treasury voucher scheme. }\end{array}$ & Met \\
\hline Begin publishing semiannual national accounts. & Not met & $\begin{array}{l}\text { Apply VAT to petroleum products at standard rate } \\
\text { and simplify other petroleum taxes. }\end{array}$ & Met & $\begin{array}{l}\text { Publish the list of companies, individuals, and } \\
\text { NGO's that have received tax exemptions each } \\
\text { quarter under the Treasury voucher scheme. }\end{array}$ & N/A \\
\hline $\begin{array}{l}\text { Complete review of statistical system in preparation } \\
\text { for GDDS. }\end{array}$ & Not met & Establish unified tax appeals mechanism. & Met & $\begin{array}{l}\text { Develop a plan to introduce a computerized risk } \\
\text { management system aimed at expediting } \\
\text { customs clearance primarily through reducing } \\
\text { significantly the number of shipments that are } \\
\text { physically inspected. }\end{array}$ & Met \\
\hline An audit of the bonded warehouses to be completed. & Met & $\begin{array}{l}\text { Begin producing comprehensive monthly flash } \\
\text { commitment and expenditure reports. }\end{array}$ & Not met & & \\
\hline $\begin{array}{l}\text { Monitoring system to be established prior to } \\
\text { computerization. }\end{array}$ & Met & Begin reporting revenue collections through IFMS. & Partially met & & \\
\hline $\begin{array}{l}\text { Revised set of national accounts on production and } \\
\text { expenditure. }\end{array}$ & $\begin{array}{l}\text { Partially } \\
\text { met }\end{array}$ & $\begin{array}{l}\text { Complete inventory of all budgetary arrears, and } \\
\text { allocate funds to eliminate them during 2000/01. }\end{array}$ & $\begin{array}{l}\text { Met with } \\
\text { delay }\end{array}$ & & \\
\hline $\begin{array}{l}\text { Foreign trade statistics using customs data to be } \\
\text { published by } 3 / 31 / 97 \text {. }\end{array}$ & Not met & $\begin{array}{l}\text { Requiring all LPOs of local spending units to be } \\
\text { generated by the IFMS through their respective sub- } \\
\text { treasuries. }\end{array}$ & Met & & \\
\hline Retrenchment of further 4,000 civil servants. & Not met & $\begin{array}{l}\text { Commence operations of the large taxpayer unit in } \\
\text { the TRA. }\end{array}$ & Delayed & & \\
\hline $\begin{array}{l}\text { Publish revised set of prod and expend stats } \\
\text { accounts. }\end{array}$ & Not met & $\begin{array}{l}\text { Eliminate all remaining tax exemptions for the } \\
\text { Government (except those constituting contractual } \\
\text { obligations). }\end{array}$ & Partially met & & \\
\hline Published foreign trade stats using customs data. & Met & $\begin{array}{l}\text { Establish an inventory of public sector domestic } \\
\text { debt as of end-June } 2001 .\end{array}$ & Met & & \\
\hline $\begin{array}{l}\text { Fully decontrol petroleum product pricing and } \\
\text { importation. }\end{array}$ & Not met & $\begin{array}{l}\text { Establish a strategy and timetable for harmonizing } \\
\text { local government taxes and levies. }\end{array}$ & Met & & \\
\hline $\begin{array}{l}\text { Complete study on policy options with respect to oil } \\
\text { refinery. }\end{array}$ & Not met & $\begin{array}{l}\text { Begin publishing the amounts and timing of budget } \\
\text { transfers to local governments. }\end{array}$ & Met & & \\
\hline $\begin{array}{l}\text { An action plan for complete or partial sale of one } \\
\text { large public enterprise to be developed. }\end{array}$ & $\begin{array}{l}\text { Partially } \\
\text { met }\end{array}$ & $\begin{array}{l}\text { Require local governments to present quarterly } \\
\text { reports of their revenue by source, and expenditure } \\
\text { by sector, from the beginning of their next fiscal } \\
\text { year. }\end{array}$ & Met & & \\
\hline
\end{tabular}




\section{ESAF 1996-1999}

PRGF 2000-2003

PRGF 2003-2006 1/

Condition

aovernment control.

Complete drafting of invitation to bid for Tanzanian Telecomm. Co.

Complete evaluation of bids for NBC subsidiaries.

Invite bids for Tanzanian Telecomm Co.

Remove 25 entities from government control.

Remove 50 entities from government control.

Offer oil refinery for divestiture.

Remove 25 entities from government control 7/1/98 and $12 / 31 / 98$

Remove 50 entities from government control 7/1/98 and 6/30/99.

Status

Condition

Adopt domestic debt strategy covering direct and continaent liabilities.

Not met

Conduct a review of the administration of the VAT.

Not met Examine alternative options for administering exemntions from indirect taxes.

Not met Publish individual and consolidated quarterly revenue and expenditure accounts of local governments starting with those for the first quarter government

Not met Adopt centralized motor vehicle registration system.

Met Introduce a treasury voucher system for administering the indirect tax exemption applying to nonreligious nongovernmental organizations and to imports of motor vehicle by eligible public servants.

Not met Issue guidelines to local councils for the harmonization of taxes. levies. and licenses.

Partially Require spending agencies (MDAs) to submit to the met Accountant General quarterly reports on their utility bill and amounts paid, starting with a report for the first nu 1 arter of $2002 / n$ ?

Partially Establish National Debt Management Committee under the National Debt Strateav.

Not met Base minimum dutiable values on international prices (except sugar).

Complete evaluation of financial proposals for Dar Salaam water and sewage authority and begin neantiations

Complete draft of regulatory framework for petroleum Not met

Harmonize the split import duty rates for all goods.
PRGF 2003

Status

sector

Harmonization of import taxes between mainland and Zanzibar

Met

Obtain government approval of reform of import duty and exemntions reaime.

Introduce preshipment inspection for private sector imnorts to Zanzibar.

$1 / 3 r d$ vear of the proaram is not completed vet: conditionalitv performance status to be reviewed marked "N/A".

Source: MONA. Staff Reborts. 


\section{REFERENCES}

Adam, C. and D. Bevan, 2004, "Aid and the Supply Side: Public Investment, Export Performance and Dutch Disease in Low Income Countries," Department of Economics Series Ref: 201, University of Oxford.

Deininger, K., and L. Squire, 1998, "New Ways of Looking at Old Issues: Inequality and Growth," Journal of Development Economics 57(2): 259-287.

Demombynes, G. and J.G.M. Hoogeveen, 2004, "Growth, Inequality, and Simulated Poverty Paths for Tanzania, 1992-2002," World Bank Policy Research Working Paper No. 3432 .

Economist Intelligence Unit, 2005, “Tanzania—Country Profile 2005,” (London, UK) International Monetary Fund, 2003, "Tanzania—Report on Discussions on a Possible New Poverty Reduction and Growth Facility Arrangement"

_ , 2003, “Tanzania-IMF Country Report No. 03/2', Available via the internet: http://www.imf.org/external/pubs/ft/scr/2003/cr0302.pdf

—_ 2003, "Tanzania—Financial System Stability Assessment, including Reports on the Observance of Standards and Codes on Banking Supervision," Available via the internet: http://www.imf.org/external/pubs/ft/scr/2003/cr03241.pdf

— , 2003, "Tanzania-Pilot Study on Access to Foreign Private Capital," Prepared by the International Capital Markets, African and Policy Development and Review Departments, unpublished.

— 2004, “Tanzania-IMF Country Report No. 04/284," Available via the internet: http://www.imf.org/external/pubs/ft/scr/2004/cr04284.pdf

_ 2004, Background paper to "Evaluation of the PRSP Process and Arrangements Under the PRGF," joint report by the IMF's Independent Evaluation Office and World Bank's Operations Evaluation Department (Washington DC).

_ 2005, "The Macroeconomic of Managing Increased Aid Inflows: Experiences of Low-Income Countries and Policy Implications"(www.imf.org).

Klasen, S., 2003, "In Search of the Holy Grail. How to Achieve Pro-Poor Growth" in Towards Pro Poor Policies, Proceedings from the ABCDE Europe Conference, eds. I. Kolstad, B. Tungodden and N. Stern, (Washington, D.C).

Ravallion, M., 2000, “Growth, Inequality and Poverty: Looking Beyond Averages," World Development 29 (11): 1803-1815. 
Treichel, V., 2005, “Tanzania's Growth Process and Success in Reducing Poverty,” IMF Working Paper WP/05/35.

World Bank, 2000, Tanzania: Country Assistance Strategy (Washington DC: The World Bank).

— 2000, World Development Report (New York: Oxford University Press).

_ 2005, Tanzania: Diagnostic Trade Integration Study (Washington DC: The World Bank).

— 2006, Doing Business In, Available via the internet: www.doingbusiness.org.

World Economic Forum, 2005, The Global Competitiveness Report 2005-2006: Policies Underpinning Rising Prosperity, eds. A. Lopez-Claros, M. E. Porter and K. Schwab. 